\title{
The European 2015 drought from a climatological perspective
}

\author{
Monica Ionita ${ }^{1,2}$, Lena M. Tallaksen ${ }^{3}$, Daniel G. Kingston ${ }^{4}$, James H. Stagge ${ }^{3}$, Gregor Laaha $^{5}$, \\ Henny A. J. Van Lanen ${ }^{6}$, Patrick Scholz ${ }^{1}$, Silvia M. Chelcea ${ }^{7}$, and Klaus Haslinger ${ }^{8}$ \\ ${ }^{1}$ Alfred Wegener Institute Helmholtz Center for Polar and Marine Research, Bremerhaven, Germany \\ ${ }^{2}$ MARUM - Center for Marine Environmental Sciences, University of Bremen, Bremen, Germany \\ ${ }^{3}$ Department of Geosciences, University of Oslo, Oslo, Norway \\ ${ }^{4}$ Department of Geography, University of Otago, Otago, New Zealand \\ ${ }^{5}$ University of Natural Resources and Life Sciences Vienna (BOKU), Institute of Applied Statistics \\ and Computing, Vienna, Austria \\ ${ }^{6}$ Hydrology and Quantitative Water Management Group, Wageningen University, \\ Wageningen, the Netherlands \\ ${ }^{7}$ National Institute of Hydrology and Water Management, Bucharest, Romania \\ ${ }^{8}$ Central Institute for Meteorology and Geodynamics, Vienna, Austria \\ Correspondence to: Monica Ionita (monica.ionita@awi.de)
}

Received: 9 May 2016 - Discussion started: 19 May 2016

Revised: 27 January 2017 - Accepted: 16 February 2017 - Published: 8 March 2017

\begin{abstract}
The summer drought of 2015 affected a large portion of continental Europe and was one of the most severe droughts in the region since summer 2003. The summer of 2015 was characterized by exceptionally high temperatures in many parts of central and eastern Europe, with daily maximum temperatures $2{ }^{\circ} \mathrm{C}$ higher than the seasonal mean (1971-2000) over most of western Europe, and more than $3{ }^{\circ} \mathrm{C}$ higher in the east. It was the hottest and climatologically driest summer over the 1950-2015 study period for an area stretching from the eastern Czech Republic to Ukraine. For Europe, as a whole, it is among the six hottest and driest summers since 1950. High evapotranspiration rates combined with a lack of precipitation affected soil moisture and vegetation and led to record low river flows in several major rivers, even beyond the drought-hit region. The 2015 drought developed rather rapidly over the Iberian Peninsula, France, southern Benelux and central Germany in May and reached peak intensity and spatial extent by August, affecting especially the eastern part of Europe. Over the summer period, there were four heat wave episodes, all associated with persistent blocking events. Upper-level atmospheric circulation over Europe was characterized by positive $500 \mathrm{hPa}$ geopotential height anomalies flanked by a large negative anomaly to the north and west (i.e., over the central North Atlantic Ocean extending to northern Fennoscandia) and another center of
\end{abstract}

positive geopotential height anomalies over Greenland and northern Canada. Simultaneously, the summer sea surface temperatures (SSTs) were characterized by large negative anomalies in the central North Atlantic Ocean and large positive anomalies in the Mediterranean basin. Composite analysis shows that the western Mediterranean SST is strongly related to the occurrence of dry and hot summers over the last 66 years (especially over the eastern part of Europe). The lagged relationship between the Mediterranean SST and summer drought conditions established in this study can provide valuable skill for the prediction of drought conditions over Europe on interannual to decadal timescales.

\section{Introduction}

Drought is part of the natural climate cycle that commonly affects large areas and can last for several months or even years. It is a complex phenomenon with wide-ranging environmental and socioeconomic impacts and is considered globally to be one of the costliest natural hazards (Wilhite, 2000; EEA, 2010). In Europe, the overall losses due to drought over the period 1976-2006 have been estimated at about EUR 100 billion (EC, 2007). Drought can affect all components of the hydrological cycle, from its origin as a 
deficit in precipitation, which combined with high evapotranspiration losses can lead to deficit in soil moisture and subsequently can manifest itself as a hydrological drought, i.e., deficits in streamflow and groundwater (Tallaksen and Van Lanen, 2004). In cold regions, a temperature anomaly may cause a similar winter drought to develop (Van Loon and Van Lanen, 2012). Consequently, drought can cause a wide range of impacts affecting the environment, society and economy, where impacts on agriculture and public water supply are most frequently reported (Stahl et al., 2016). Prolonged droughts with severe impacts, such as the major drought in 2003, have highlighted Europe's vulnerability to this natural hazard and alerted governments, stakeholders and operational agencies to the disastrous effects droughts may have on the society and economy, including the need for mitigation measures (EEA, 2001, 2010; EC, 2012).

The year 2015 was characterized by one of the worst droughts recorded in Europe, particularly in the central and eastern part of the continent (Van Lanen et al., 2016). The 2015 summer (June-July-August (JJA)) was the thirdwarmest summer in Europe since 1910 (after 2003 and 2010), and coincided with the warmest month (August 2015) and year (2015) on record, with a global temperature anomaly of $0.9^{\circ} \mathrm{C}$ above the 20th century average (NOAA, 2016). Record high temperatures were recorded at several places in Europe in July and August 2015, including Kitzigen in Germany $\left(40.3^{\circ} \mathrm{C}\right)$, Catania in Italy $\left(42.8^{\circ} \mathrm{C}\right)$, Córdoba in Spain $\left(45.2^{\circ} \mathrm{C}\right)$, Dobriichovice in the Czech Republic $\left(39.8^{\circ} \mathrm{C}\right)$ and Yerevan in Armenia $\left(40.9{ }^{\circ} \mathrm{C}\right)$. In some countries (e.g., Czech Republic), it was the second-driest summer of the last 50 years, where only 2003 had lower rainfall (Van Lanen et al., 2016). The drought was accompanied by extreme low flows, especially over the central and eastern parts of Europe, and caused serious socioeconomic impacts in various water-related sectors (Van Lanen et al., 2016).

The 2015 event was extreme, but not singular. In fact, the beginning of the 21 st century has seen an increase in the frequency of prolonged droughts and heat waves in Europe, including the event of 2003 that affected large parts of central Europe. Other major events include the drought in 2008 over the Iberian Peninsula (Andreu et al., 2009), the drought and heat wave in Russia in 2010 (Barriopedro et al., 2011), and the spring drought of 2011 over western parts of Europe. As average global temperatures continue to rise, it is estimated that droughts will further intensify in the 21 st century, particularly in certain seasons and regions, e.g., in southern and eastern Europe (Stagge et al., 2014; Spinoni et al., 2016), parts of North America, Central America, and southern Africa (Seneviratne et al., 2012; Orlowsky and Seneviratne, 2013; Prudhomme et al., 2013; Wanders et al., 2015).

A better understanding of the spatial and temporal development of these major drought events, in particular their triggering mechanisms and persistence, is vital to enable a better prediction of prolonged dry periods and extensive drought extent (Tallaksen and Stahl, 2014; Van Huijgevoort et al., 2013). Persistent dry (wet) conditions are usually associated with anticyclonic (cyclonic) circulation, while the sea surface temperatures (SSTs) can play also an important role via the interaction with large-scale climatic or oceanic modes of variability (e.g., North Atlantic oscillation (NAO), El Niño-Southern Oscillation (ENSO); Ionita et al., 2011, 2015; Schubert et al., 2014). Altogether, when favorable phase conditions are met, both large-scale atmospheric as well as oceanic factors could act as precursors to dry (wet) summers over Europe (Kingston et al., 2013, 2015; Ionita et al., 2012, 2015).

This paper summarizes a collaborative initiative of members of UNESCO's FRIEND-Water programme to perform a pan-European assessment of the drought of 2015 from a climatological point of view. In an accompanying paper (Laaha et al., 2016), a similar pan-European assessment of the drought from a hydrological perspective is performed with a focus on streamflow records. Impacts and examples of how the drought of 2015 was managed are described by Van Lanen et al. (2016). The objectives of this paper are as follows: (a) to characterize the temporal and spatial extent of the summer 2015 drought event using both daily and monthly climate data (surface level analyses); (b) to analyze the key drivers of the event, with a special emphasis on the role played by the SST and large-scale (atmospheric) circulation modes of variability (upper-level analyses); (c) to compare the key characteristics of the 2015 drought with the 2003 event and (d) to place the summer 2015 drought event into a long-term perspective.

The paper is organized as follows: Sect. 2 gives an introduction to the data and methods used. The results of surface analysis of the summer drought of 2015 are shown in Sect. 3, while the prevailing ocean-atmosphere conditions are presented in Sect. 4. The similarities and differences with the summer event of 2003 and the long-term context of the 2015 event are shown in Sect. 5. A detailed discussion is given in Sect. 6, while the concluding remarks and some recommendations are provided in Sect. 7.

\section{Data and methods}

\subsection{Climate, oceanic and hydrologic data}

Climate variables, i.e., daily time series of precipitation $(P)$, mean temperature $(T)$ and maximum temperature $\left(T_{x}\right)$, originate from the E-OBS dataset (Haylock et al., 2008). EOBS is a daily gridded observational dataset for precipitation, minimum, mean and maximum temperature and sea level pressure in Europe. It is based on the European Climate Assessment and dataset (ECA\&D) station information. The full version dataset covers the period 1 January 1950 until 31 December 2015, in total 66 years. For this study, we use the regular $0.25^{\circ} \times 0.25^{\circ}$ latitude-longitude grid. 
Daily outgoing long-wave radiation (OLR) was extracted from NOAA Interpolated Outgoing Longwave Radiation dataset (Liebmann and Smith, 1996). For the Northern Hemisphere atmospheric circulation, we use the daily and monthly means of geopotential height at $500 \mathrm{hPa}(\mathrm{Z} 500)$ and $850 \mathrm{hPa}$ (Z850) levels, the zonal wind at $850 \mathrm{hPa}$ level (U850), $500 \mathrm{hPa}$ level (U500) and $250 \mathrm{hPa}$ level (U250), the meridional wind at $850 \mathrm{hPa}$ level (V850) and $500 \mathrm{hPa}$ level (V500), and the mean sea level pressure (SLP) from the NCEPNCAR 40-year reanalysis project (Kalnay et al., 1996) on a $2.5^{\circ} \times 2.5^{\circ}$ grid. The vertically integrated water vapor transport (WVT) (Peixoto and Oort, 1992) is calculated using zonal wind $(u)$, meridional wind $(v)$ and specific humidity $(q)$, also from the NCEP-NCAR reanalysis (Kalnay et al., 1996). WVT vectors for latitude $(\varphi)$ and longitude $(\lambda)$ are defined as follows:

$$
\boldsymbol{Q}(\lambda, \varphi, t)=Q_{\lambda} \boldsymbol{i}+Q_{\varphi} \boldsymbol{j}
$$

where zonal $\left(Q_{\lambda}\right)$ and meridional $\left(Q_{\varphi}\right)$ components of $Q$ are given by Eq. (2):

$$
\begin{aligned}
Q_{\lambda} & =\int_{0}^{p_{0}} q u \frac{\mathrm{d} p}{g}, \\
Q_{\varphi} & =\int_{0}^{p_{0}} q v \frac{\mathrm{d} p}{g} .
\end{aligned}
$$

For each vertical layer and each grid point, we calculate the product between the monthly values of horizontal wind $(u)$ and specific humidity $(q)$. The result is multiplied with the pressure thickness of the layer they represent and divided by gravity. The WVT is obtained by summation of water transport for all layers located between the Earth's surface and $300 \mathrm{hPa}$ level. We also used the divergence of water vapor $K$, which is in balance with the surface fresh water flux $E-P$ (Peixoto and Oort, 1992):

$\nabla \cdot Q=E-P$,

where $\nabla$ denotes the two-dimensional divergence operator, $E$ is evaporation and $P$ is precipitation. Regions of mean positive divergence $(E-P>0)$ constitute source regions of water vapor, whereas regions of convergence $(E-P<0)$ are sink regions for water vapor.

Global SST is extracted from the Extended Reconstructed Sea Surface Temperature dataset (ERSSTv4b; Liu et al., 2014). This dataset covers the period 1854-2015 and has a spatial resolution of $2^{\circ} \times 2^{\circ}$. For daily SST, we use the OISST dataset (Reynolds at al., 2007).

\subsection{Climatological drought indices (SPI and SPEI)}

The Standardized Precipitation Index, SPI (McKee et al., 1993; Guttman, 1999), and the Standardized Precipitation Evapotranspiration Index, SPEI (Vicente-Serrano et al., 2010; Beguería et al., 2013), are used as indicators for meteorological and/or climatological drought. The SPI has become a favored meteorological drought index in Europe and is recommended by the World Meteorological Organization (Hayes et al., 2011; WMO, 2012). The more recently developed SPEI uses a similar methodology, but includes a more comprehensive formulation of the climatic water balance that may better quantify drought (Beguería et al., 2013). The SPI and SPEI normalize accumulated precipitation $(P)$ and climatic water balance $(P-\mathrm{PE})$, respectively, where PE represents the potential evapotranspiration. By taking into account different accumulation periods, both indices have a multiscalar feature, and hence give the user the possibility to approximate agricultural, hydrological and socioeconomic drought by adjusting the accumulation period for a particular region (Vicente-Serrano et al., 2011; Hayes et al., 2011). Here, we use an accumulation period of 3 months for both indices, hereafter referred to as SPI3 and SPEI3, both derived relative to a reference period of 1971-2000. The index values represent the number of standard deviations from typical conditions for a given location and time of year and therefore allow for objective, relative comparison across locations with different climatologies and non-normal precipitation distributions (Stagge et al., 2015). A negative SPI or SPEI represents values lower than the median, and values less than -2 are considered to represent extremely dry conditions, corresponding to a 1-in-50-year event (WMO, 2012). A 3-month accumulation period was chosen to capture the seasonal development of the drought and enable comparison with monthly anomalies in $P$ and $T$. Kingston et al. (2015) concluded that atmospheric anomalies associated with major drought events were very similar whether a 3- or 6-month accumulation period was used.

Potential evapotranspiration (for the computation of SPEI) was calculated using the Hargreaves equation (Hargreaves and Samani, 1985). This method uses the daily difference between maximum daily temperature $\left(T_{x}\right)$ and minimum daily temperature $\left(T_{\mathrm{n}}\right)$ as a proxy to estimate net radiation. Use of the Hargreaves equation when calculating SPEI has shown to be robust for Europe, providing similar results to more complex models (Stagge et al., 2014).

\subsection{Teleconnection indices}

Teleconnection indices for the North Atlantic Oscillation (NAO), the Arctic Oscillation (AO), the Scandinavian (SCA) and the eastern Atlantic (EA) patterns, have been downloaded from http://www.cpc.ncep.noaa.gov/data/ teledoc/teleintro.shtml for the period 1950-2015. The Niño 3.4 index was used to characterize ENSO, and is defined as the averaged SST anomalies over the domain $170-120^{\circ} \mathrm{W}$, $5^{\circ} \mathrm{S}-5^{\circ} \mathrm{N}$. 
(a)

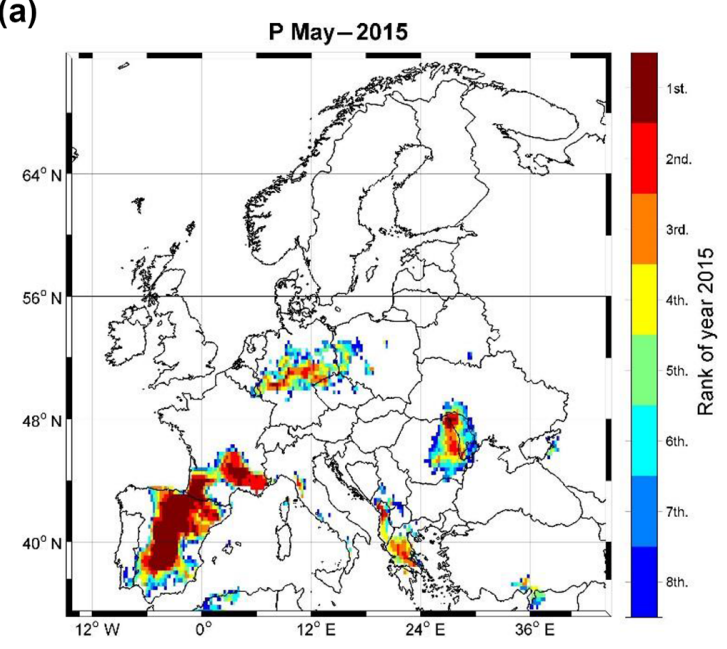

(c)

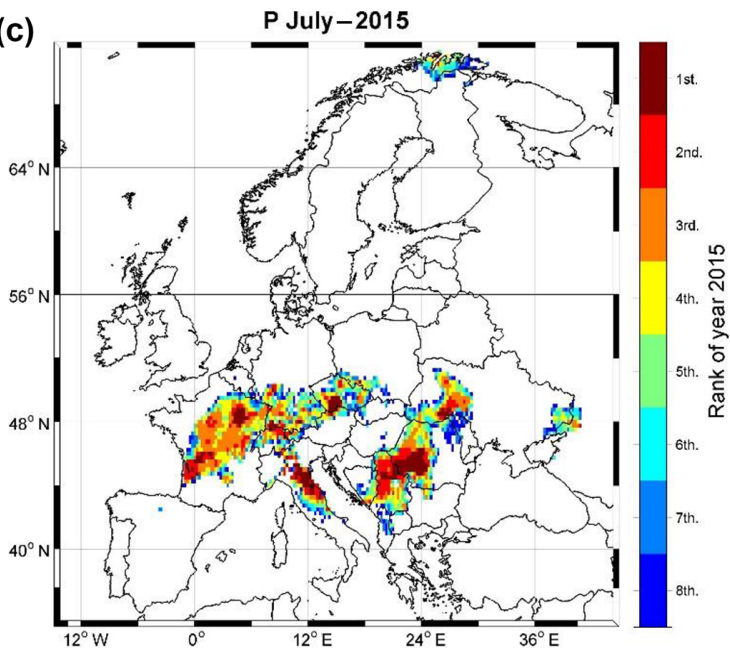

(b)

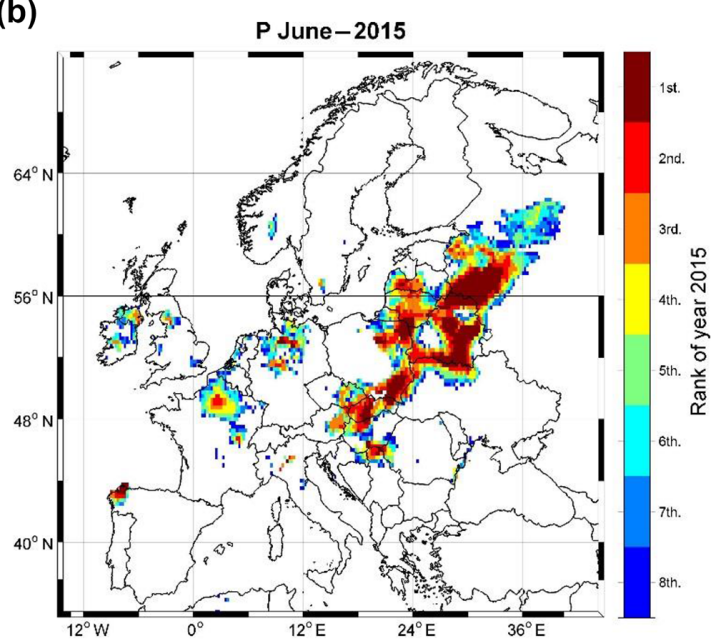

(d)

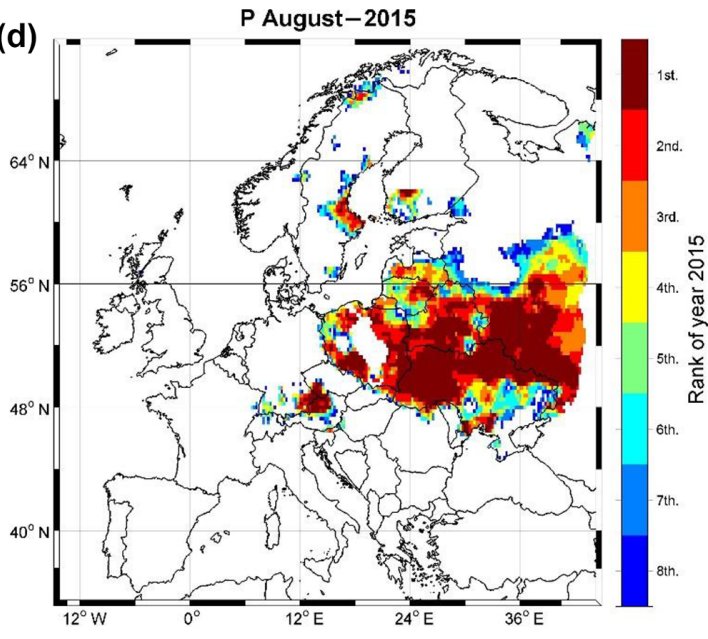

Figure 1. Top-eight ranking of 2015 monthly lowest $P$ : (a) May; (b) June; (c) July and (d) August. 1 means the driest month since 1950, 2 signifies the second driest, etc., and all ranks greater than 8 are shown in white. Analyzed period: 1950-2015.

\subsection{Methods}

\subsubsection{Ranking maps}

In order to put the summer 2015 summer drought in a longterm context, ranking maps for monthly $P$ (Figs. 1 and 7), $T_{x}$ (Figs. 2, 7 and 9), SPI3 and SPEI3 (Figs. 3 and 9), and SST (Figs. 11 and S3) have been computed of the first eight driest and/or warmest years on record) in each grid point.

\subsubsection{Composite maps}

To identify the physical mechanism responsible for the connection between the summer drought conditions and the large-scale atmospheric circulation and North Atlantic SST, we constructed composite maps of the difference between the time series August SPEI3 index averaged over the $18^{\circ} \mathrm{E}-$ $32^{\circ} \mathrm{E}, 48-52^{\circ} \mathrm{N}$ region for the years when the index was greater and lower than a value of 0.75 . This threshold was chosen as a compromise between the strength of the climate anomalies associated with summer drought conditions and the number of maps satisfying this criterion. Further analysis has shown that the results are not sensitive to the exact threshold value used for our composite analysis (not shown). We have computed composite maps, instead of correlation maps, because the former considers the nonlinearities included in the analyzed data. The significance of the composite maps is based on a standard $t$ test (confidence level $95 \%$ ).

\section{Climate conditions and drought indices}

\subsection{Precipitation and maximum temperature}

The summer 2015 drought and heat wave as measured by the rank maps of the monthly lowest precipitation totals and the maximum daily temperature (for the months May to August) are shown in Figs. 1 and 2. The most-affected regions during 
the summer 2015 event were the central and eastern parts of Europe and the northern Balkans.

In May, abnormally dry and warm conditions started to develop over the Iberian Peninsula, southeastern France, southern Benelux and Germany (Figs. 1a and S1a in the Supplement). May 2015 is ranked as the driest and hottest May in the 1950-2015 study period over the central and eastern Iberian Peninsula, and the second-driest May over a small band covering the central part of Germany and eastern Romania (Fig. 1a).

June 2015 ranks as either the driest or second-driest month in the study period across the eastern part of Europe (Fig. 1b). As a consequence, in June, the spatial distribution of belownormal precipitation moved north and eastwards, covering central parts of Europe, the northern Balkans and parts of Belarus and Ukraine (Fig. S1c). By July 2015, drought conditions were well established. The rainfall deficit over the central, southern and eastern parts of Europe was more than $75 \mathrm{~mm}$ ( $\sim 40 \%$ of total precipitation) (Fig. S1e). July 2015 saw drought intensity slightly decreasing in many regions (Fig. 1c), with a region of moderate drought in central France, but extremes in western Romania continuing from June. This eastern European center of the drought expanded significantly in August 2015, ranking as the driest month in these regions (Fig. 1d), with large precipitation deficits across the larger central and eastern European region, together with a smaller area over Finland and the Scandinavian Peninsula (Fig. S1g).

In contrast to the warming in southwestern Europe in May, negative temperature anomalies were recorded in northwestern Europe, particularly in Scandinavia (Fig. S1b). In June, major parts of the European continent experienced aboveaverage daily maximum temperatures, with anomalies of more than $3{ }^{\circ} \mathrm{C}$ in an area stretching from the Iberian Peninsula through central and eastern France, the western Alps and Ukraine (Fig. S1d). In July, the heat wave intensified with anomalies as high as $5^{\circ} \mathrm{C}$ over France. The area affected also expanded and became more clearly defined, stretching from Spain and France up to the eastern and central parts of Europe, western Ukraine and the Balkans (Fig. S1f). July 2015 was the hottest July on record over Spain, large parts of Italy and the Czech Republic and the second hottest July over the central and eastern parts of France and in some areas in the eastern part of Europe (Fig. 2c). In contrast, July 2015 was cooler than normal in northwestern Europe, with anomalies up to $-5^{\circ} \mathrm{C}$ over Fennoscandia and northwestern part of Russia (Fig. S1f). In August, the heat wave was no longer present over the Iberian Peninsula and southern France, but continued to develop in central and eastern Europe, with anomalies of up to $5{ }^{\circ} \mathrm{C}$ over Poland and the western part of Ukraine (Fig. S1h). August 2015 is ranked as the hottest August on record across most of Poland, Ukraine and Belarus, and the second-hottest August over a broader area extending from France in the west to Belarus in the east and covering latitudes from northern Romania to Latvia (Fig. 2d).
The northern part of Europe also experienced a relatively warm August (Fig. S1h).

Throughout the summer, four heat wave episodes (defined as $T_{x}>25^{\circ} \mathrm{C}$ ) can be identified in Europe based on averaging the daily maximum temperature over the affected region (approximately $0-30^{\circ} \mathrm{E}$ and $40-55^{\circ} \mathrm{N}$ ) (Fig. S3). The highest maximum temperatures were recorded in the first 10 days of August.

\subsection{Drought indices: the SPI and SPEI}

The SPI 3 and SPEI 3 for June, July and August (Figs. 3 and S2) show similar development in time to the climate variables, with the area most affected shifting from southwestern parts of Europe in June and July, towards the central and eastern parts of Europe in August. Although monthly precipitation over France is above average in August (Fig. S1g), the climatic water-balance drought conditions still persist, especially over the western part of the country. SPI and SPEI values as low as -3 are recorded in August (Fig. S2f), and the most extreme values were found in southern Spain, parts of France and Germany, Belarus, and western Ukraine. Similar to the $P$ and $T_{x}$ pattern, June-August 2015 SPI3 and SPEI3 ranks as the driest 3 months on record over regions covering the eastern part of Europe.

Figures 1 and 3 (and S1, S2) show that the rainfall deficit and climatological drought conditions persisted for almost 3 months over large regions in Europe. At the same time, other regions in Europe received above-average precipitation, especially in the northern and northwestern parts of Europe and Fennoscandia. In summary, the summer of 2015 was characterized by a dipole-like structure with rainfall deficit and climatological drought (SPI and SPEI) in the central and southern parts of Europe, and positive anomalies (P and SPI and SPEI) over Fennoscandia and the British Isles. Drought conditions during the summer months of 2015 appear more spatially extended for SPEI3 (which also incorporates temperature information) as compared to SPI3 (which is solely based on precipitation). For example, July SPI3 does not show July 2015 as the driest month on record over Spain (Fig. 3c), whereas the July SPEI3 does (Fig. 3d). This is likely due to the generally low seasonal precipitation in this region, which makes distinguishing between precipitation-based drought anomalies (SPI3) difficult. In contrast, accounting for potential evapotranspiration in the SPEI3 highlights the severity of this drought, with July 2015 ranked as the hottest on record in Spain (Fig. 2c). This suggests that the SPEI is a more comprehensive measure of drought climatological drought severity and is preferred to the SPI in the remainder part of this paper. Similar results have been found by Hoy et al. (2016), who showed that SPEI and the Water Balance Anomaly Index (WBAI) are a better estimate of drought severity compared to precipitation based drought indices (SPI). 

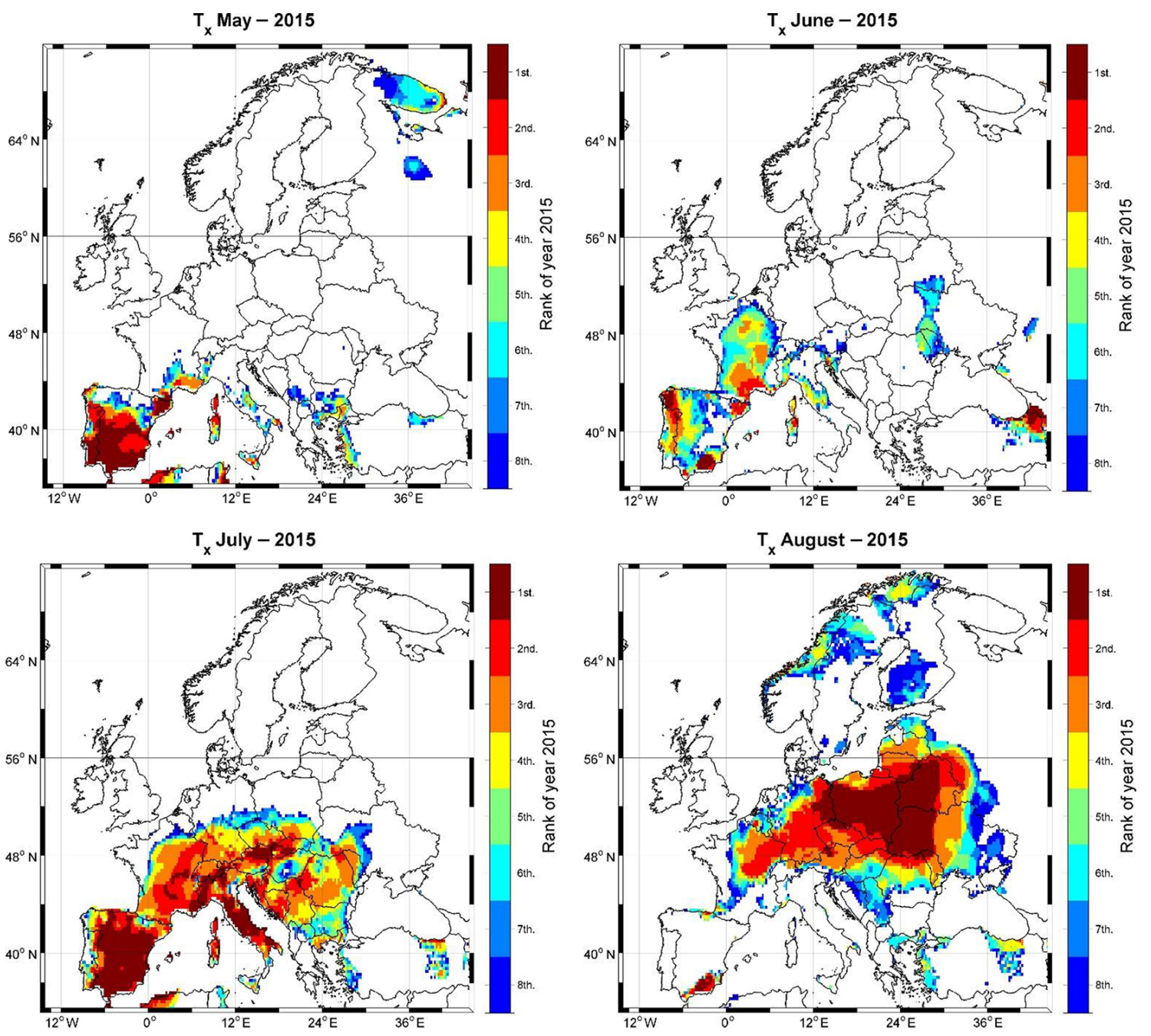

Figure 2. Top-eight ranking of 2015 monthly $\mathrm{T}_{x}$ : (a) May; (b) June; (c) July and (d) August. 1 means the warmest month since 1950, 2 signifies the second warmest, etc., and all ranks greater than 8 are shown in white. Analyzed period: 1950-2015.

\section{Ocean-atmosphere conditions}

\subsection{Sea surface temperature (SST)}

Figure 4 shows the evolution of the SST anomalies between May 2015 and August 2015. The corresponding rank maps are shown in Fig. S3. At the beginning of May, the Mediterranean Sea was up to $1^{\circ} \mathrm{C}$ warmer compared to climatology. At the same time, the North Atlantic Ocean was characterized by three distinct anomalous SST centers: (i) high SSTs in the central Atlantic Ocean extending from the east coast of the USA up to the western coast of southern Europe and the Mediterranean Sea; (ii) low SSTs southeast of Greenland and (iii) high SSTs poleward of $65^{\circ} \mathrm{N}$ (Fig. 4a). In terms of extremes, May 2015 was the sixth-coldest May over a small region in the central North Atlantic Ocean (Fig. S3a) and the second-warmest May over the western part of the Mediterranean Sea (Fig. S3b).
In June, the SST pattern persisted and the anomalous SST anomalies southeast of Greenland and in the Mediterranean Sea intensified (Fig. 4b). The cold region in the North Atlantic Ocean is ranked as having the coldest June over the last 154 years and the western part of the Mediterranean Sea is ranked as having the fourth-warmest June (Fig. S3c and S3d, respectively). In July, the warm anomaly in the Mediterranean Sea further intensified (Fig. 4c), with SST values exceeding $28^{\circ} \mathrm{C}$ (Fig. S4). The extreme warm anomaly in July is consistent with the strong extreme maximum temperature anomalies recoded over most of Europe in July (Fig. 2c). The warm anomaly in the Mediterranean Sea and the Atlantic Ocean in the $20-40^{\circ} \mathrm{N}$ band was accompanied by a similar strong negative anomaly of $\sim 1.5^{\circ} \mathrm{C}$ in the northern part of the Atlantic Ocean (Fig. 4c). The western part of the Mediterranean Sea ranks as having the warmest July on record. Record-breaking SSTs also occurred in the eastern central Atlantic (Fig. S3f). 
(a)

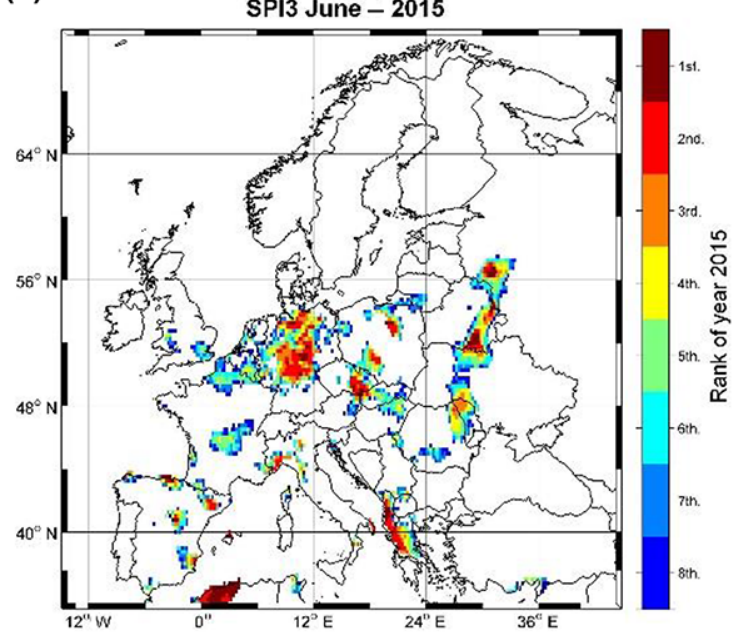

(c)

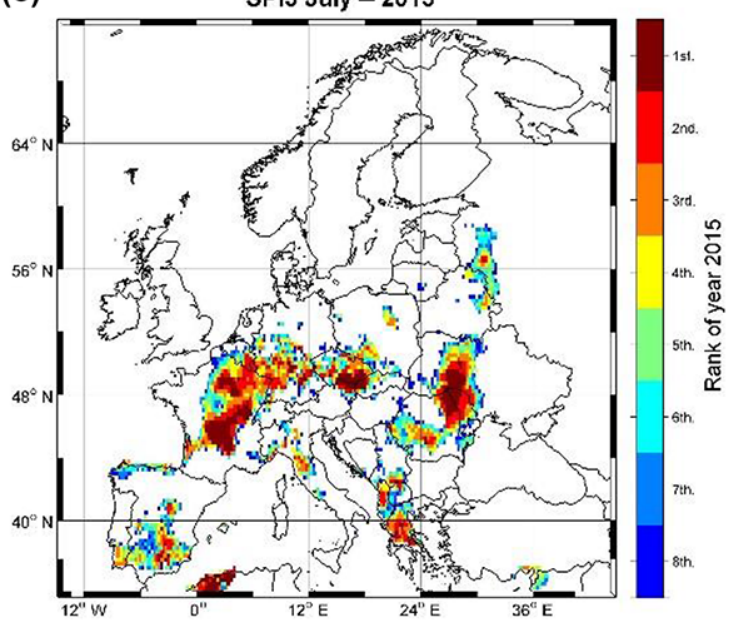

(e)

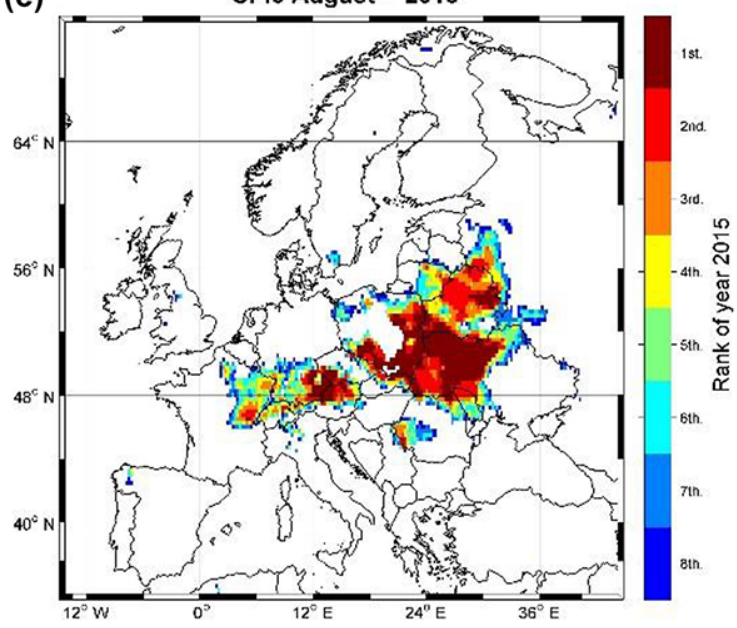

(b)

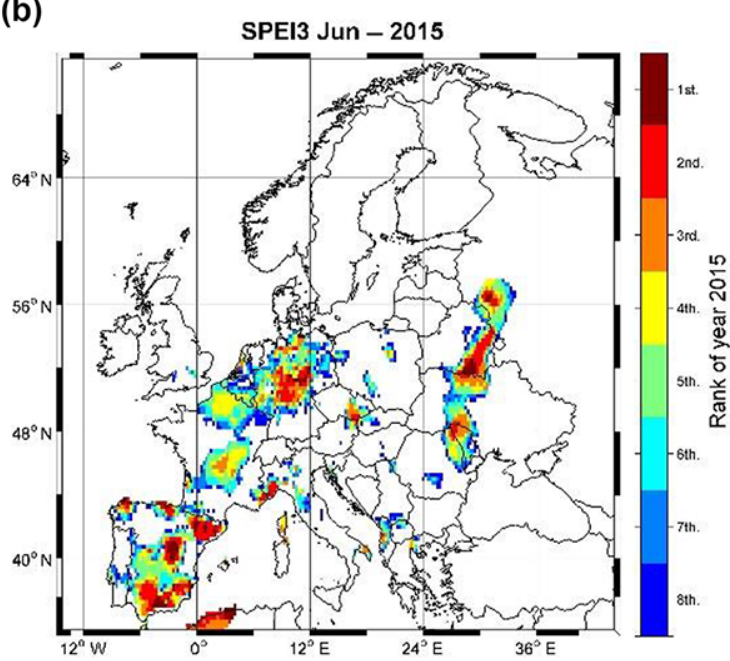

(d)

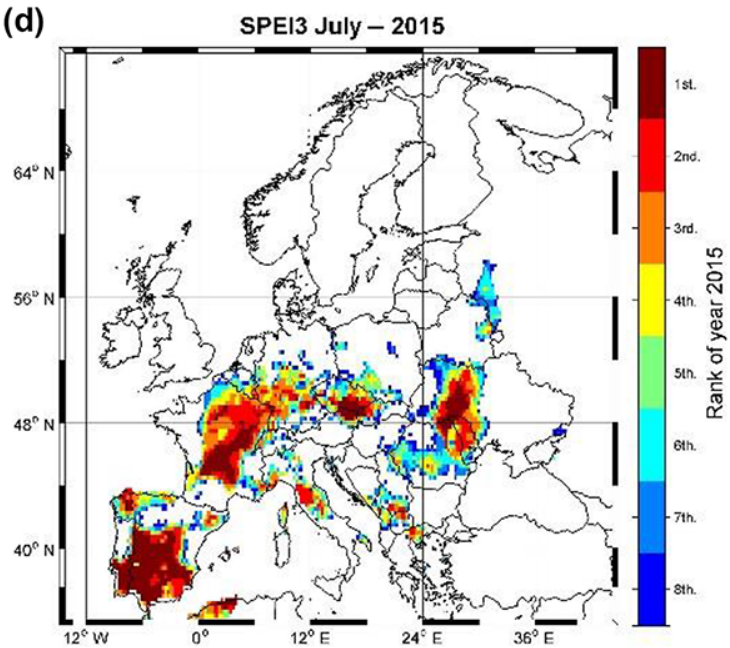

(f)

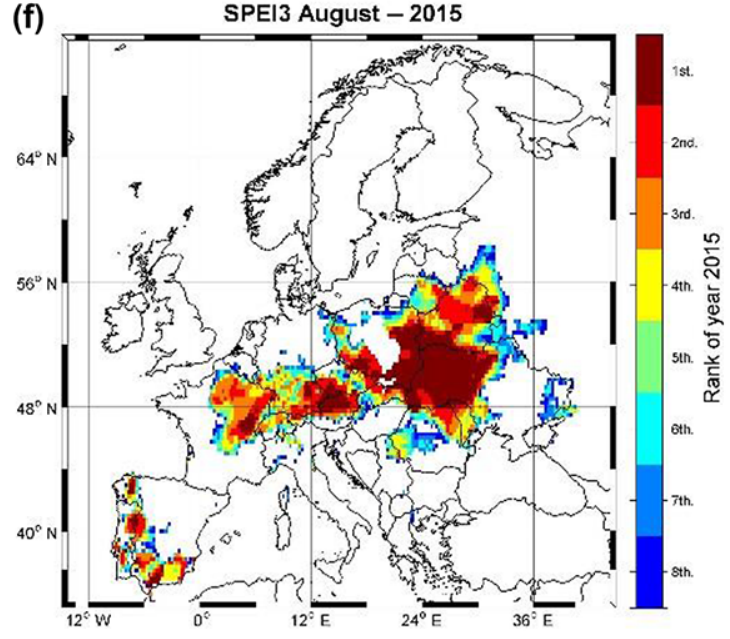

Figure 3. Top-eight ranking of 2015 monthly SPI3 (left column) and 2015 SPEI3 (right column): (a) June SPI3; (b) June SPEI3; (c) July SPI3; (d) July SPEI3; (e) August SPI3 and (f) August SPEI3. 1 means the driest month since 1950, 2 signifies the second driest, etc., and all ranks greater than 8 are shown in white. Analyzed period: 1950-2015. 
(a)

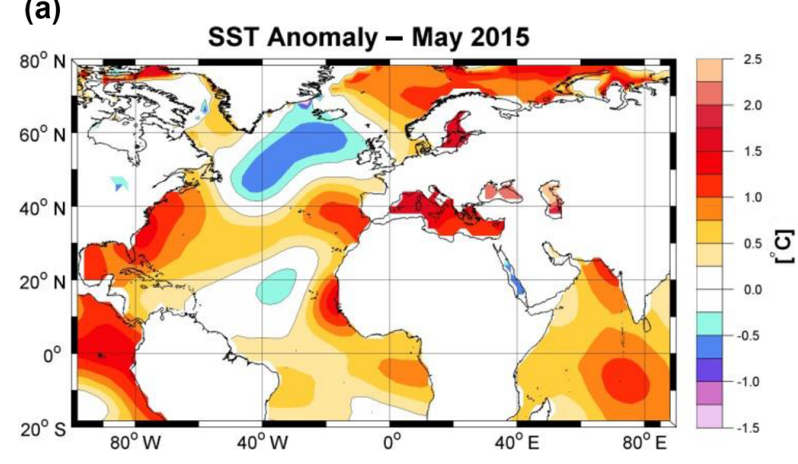

(c)

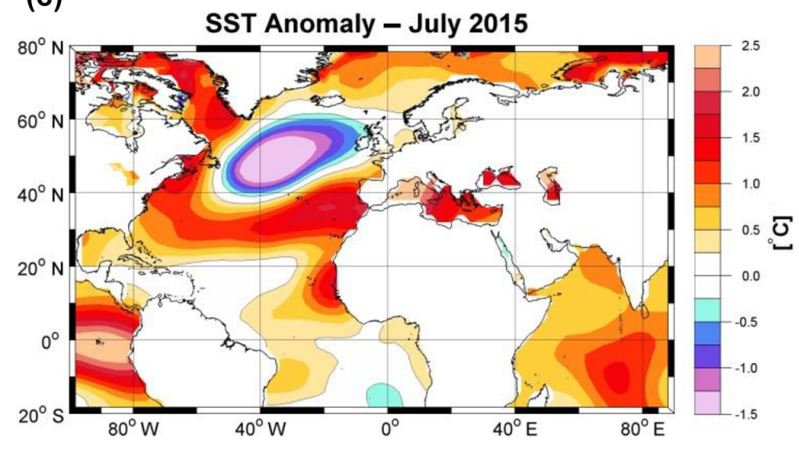

(b)

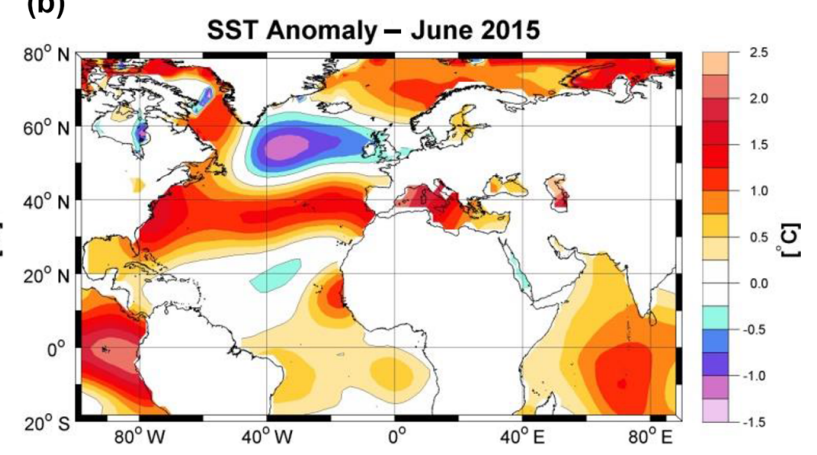

(d)

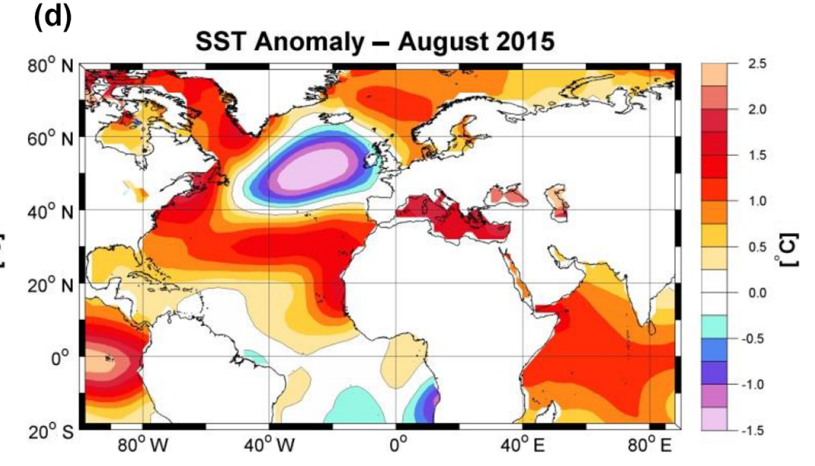

Figure 4. Monthly SST anomalies: (a) May 2015; (b) June 2015; (c) July 2015 and (d) August 2015. The anomalies are computed relative to the period 1971-2000.

In August, the warmth in the Mediterranean Sea and the Atlantic Basin in the $20-40^{\circ} \mathrm{N}$ band and the cooling south of Greenland persisted, with almost the same amplitude (Fig. 4d). The altering (positive-negative-positive) spatial pattern in the SST anomalies was present throughout the summer in the Atlantic Ocean basin, suggesting that the airsea interaction associated with the northward shift of the subtropical high plays an important role (Czaja and Frankignoul, 2002; Huang and Shukla, 2005). The SSTs in the Mediterranean Sea were again in the top eight warmest Augusts on record (Fig. S3g). The SSTs in the Atlantic basin, centered around the $30^{\circ} \mathrm{N}$ band, rank in the first three warmest $\mathrm{Au}$ gusts (Fig. S3g). In contrast to this, the small region in the central North Atlantic Basin ranks in the first eight coldest Augusts (Fig. S4f).

In the following, we investigate more closely the evolution of the daily SST anomalies that might have influenced the European climate throughout the summer of 2015, either directly or via teleconnections. First, we have computed two time series of daily SST anomalies to encapsulate the two key anomaly areas: the central North Atlantic Ocean ( -30 to $\left.-10^{\circ} \mathrm{E} ; 50-60^{\circ} \mathrm{N}\right)$ and the western Mediterranean Sea $(0$ $\left.25^{\circ} \mathrm{E} ; 30-45^{\circ} \mathrm{N}\right)$. These two regions are chosen based on the rank maps in Fig. S3. In a similar manner, we computed a daily SPEI3 index, averaged over the area affected the most by the drought conditions in summer $2015\left(18-32^{\circ} \mathrm{E}\right.$; 48$52^{\circ} \mathrm{N}$ ). This area was chosen based on the ranking map for
SPEI3 (June-August; Fig. 3f) and comprises the region that ranks as the driest on record.

Figure 5a shows the daily SST evolution from January to December 2015. A pronounced and abrupt increase in the SST anomalies over the Mediterranean Sea took place at the end of June 2015 over a period of $\sim 3$ weeks, when there was a marked increase in the SST of $\sim 2{ }^{\circ} \mathrm{C}$ accompanied by a similar abrupt cooling in the central North Atlantic Ocean of $\sim 1^{\circ} \mathrm{C}$. As demonstrated in Fig. 5a, the SST anomalies in the Mediterranean Sea are accompanied by similar SST anomalies in the central North Atlantic Ocean, but of opposite sign throughout 2015. A similar dipole-like structure of warm Mediterranean Sea-cold central North Atlantic Ocean was found to be involved in triggering the heat waves in summer 2003 (Feudale and Shukla, 2007, 2010a). In terms of long-term anomalies, the summer of 2015 stands out as third-coldest summer over the central North Atlantic Ocean (Fig. 11c) and the third-warmest one in the western Mediterranean Sea (Fig. 11d). The warmest SSTs in the Mediterranean Sea (2003, 2010 and 2015) over the last 160 years occurred in connection with extreme heat waves and largescale droughts in Europe. The daily evolution of the western Mediterranean Sea SST index and the daily SPEI index is shown in Fig. 5b. By applying a cross-correlation analysis between the two time series, it has been observed that the highest correlation ( $r=-0.8,99 \%$ significance level) is found when the western Mediterranean Sea SST index leads 

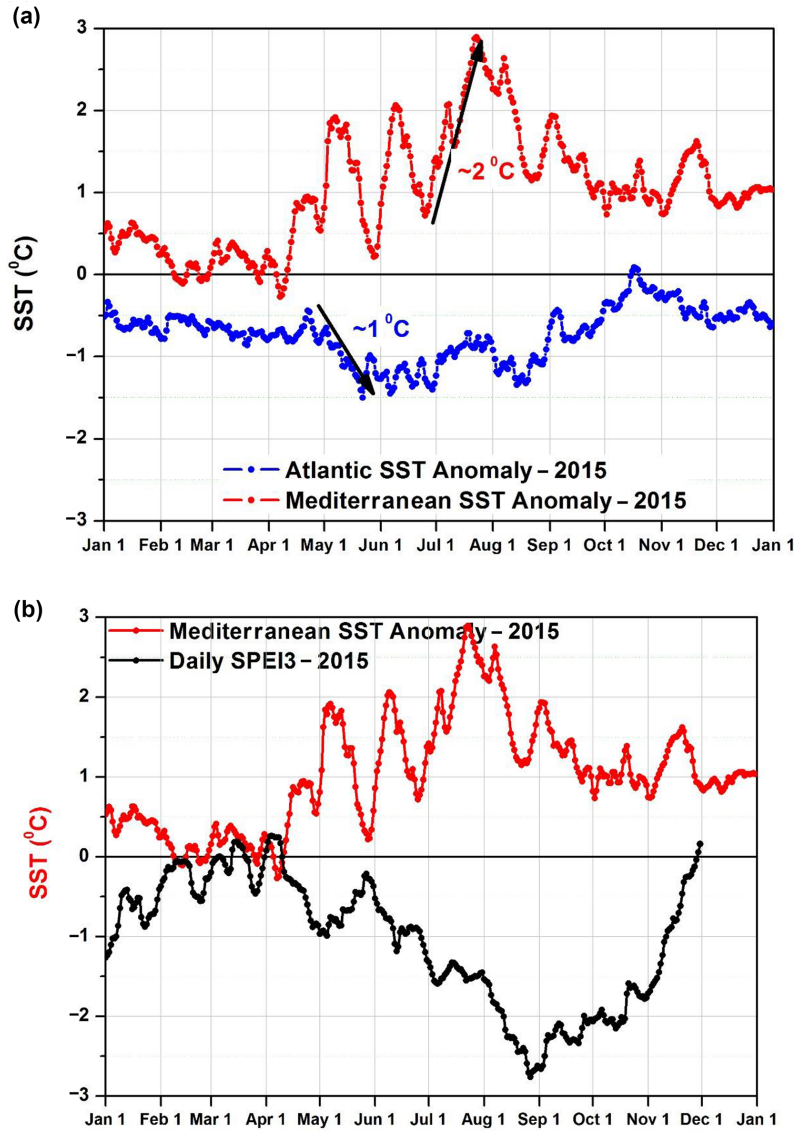

Figure 5. (a) 2015 Daily SST anomalies computed over the central Atlantic Ocean (blue line) and the Mediterranean Sea (red line); (b) 2015 Daily SPEI3 computed over the eastern part of Europe (black line) and the Mediterranean Sea (red line). The daily SST indices are based on the OISST dataset (Reynolds at al., 2007).

the SPEI3 index by $\sim 25$ days. Similar analysis has been done for the SPEI3 daily index and the North Atlantic Ocean SST index, but the correlation is much smaller $(r=0.4$, when the North Atlantic Ocean SST index leads the SPEI3 index by $\sim 50$ days). A more detailed discussion regarding the influence of these two particular regions (western Mediterranean Sea SST vs. North Atlantic Ocean SST) on the occurrence of dry summer over the eastern part of Europe is given in Sect. 5.3.

\subsection{Geopotential height at $500 \mathrm{hPa}$ and the outgoing long-wave radiation (OLR)}

During May 2015, Fennoscandia and the British Isles were under the influence of cyclonic conditions, whereas the Iberian Peninsula and the southwestern part of France were affected by anticyclonic conditions (Figs. 6a and S8a) and increased OLR anomalies associated with reduced cloud cover and precipitation over these regions (Fig. 6b). In June 2015 , the anticyclonic circulation extended from the eastern
North Atlantic Ocean up to central Europe, Belarus, Ukraine and the Balkans, while the cyclonic flow extended from the North Atlantic Ocean over Fennoscandia up to the northern part of Russia (Figs. 6c and S8b). These Z500 anomalies were accompanied by increased OLR anomalies over France, Ukraine and the Mediterranean Sea (Fig. 6d). In June and July 2015, there was an obvious wave train of altering Z500 anomalies: negative, but weak, Z500 anomalies over centralnorthern Canada, positive Z500 anomalies over Greenland, negative Z500 anomalies over Northern Atlantic Basin and Fennoscandia, and positive Z500 anomalies over central and southern parts of Europe (Fig. 6c and e). This wave train was accompanied by excessive precipitation (e.g., Fig. S1) and reduced OLR anomalies over Scandinavia and the British Isles, and heat waves, dryness and increased OLR anomalies over the Iberian Peninsula, central Europe and the Balkans.

In August 2015, the Z500 anomalies are projecting onto an $\Omega$-like block pattern with positive Z500 anomalies over Alaska and Greenland, followed by negative Z500 anomalies in the middle of the North Atlantic Ocean and an anomalous positive center over Europe (Fig. 6g). The anomalous Z500 center over Europe suggests a dominant subsidence and adiabatic warming associated with reduced cloudiness and increased incoming solar radiation (Fig. 6h).

Since there were four consecutive heat wave episodes (Fig. S5) with small interruptions in between, daily evolution of the atmospheric circulation and WVT averaged over the heat wave episodes were examined (Fig. S6). All four heat wave episodes were associated with atmospheric blocking situations dominated by a southwesterly flow regime and a northward shift of the storm tracks (red arrows in Fig. S6 - left panels). The highest daily maximum temperatures occurred, in each of the four cases, near the center of the block, where descending motion and reduced cloudiness contributed to anomalously high temperatures and dryness. To the east of the heat wave region, anomalously low temperatures occurred in conjunction with an upper-level trough and cold air intrusions from the north. During the first two heat wave episodes (29 June-8 July, 15-26 July), the vector plots of the WVT show a clear deflection of the storm track away from the central and southern parts of Europe (Fig. S6b and S6d). The axis of the WVT is directed through the British Isles and Fennoscandia, in agreement with the positive precipitation anomalies and low temperatures recorded over these areas in June and July (Fig. S1). The two episodes recorded in August (1-16 August and 26-31 August) show a distinct pattern with the axis of the WVT deflected northwards, resulting in an extended area (the whole of Europe and Fennoscandia) affected by positive temperature anomalies and precipitation deficit (Fig. S6f and S6h). In agreement with these findings, Ionita et al. (2012) have shown that periods characterized by low streamflow anomalies over the Rhine River catchment area are associated with a northward shift of the Atlantic storm tracks, whereas periods with high 
(a)

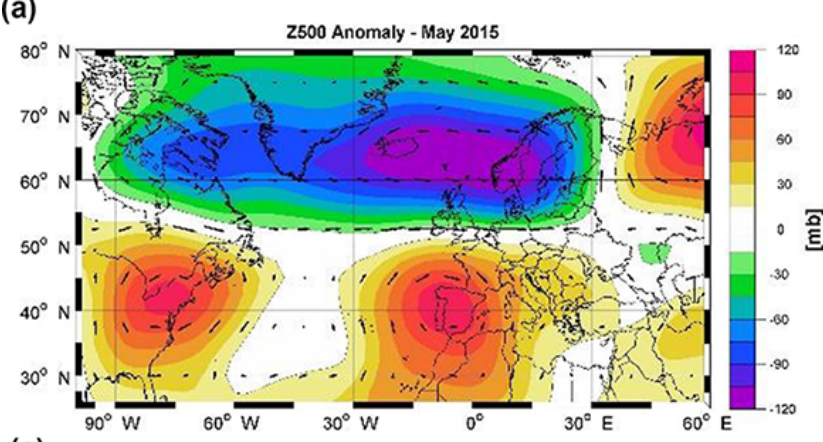

(c)

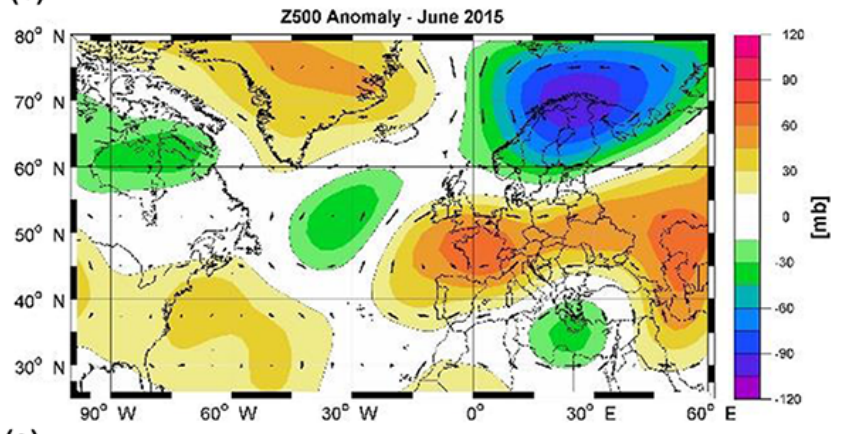

(e)

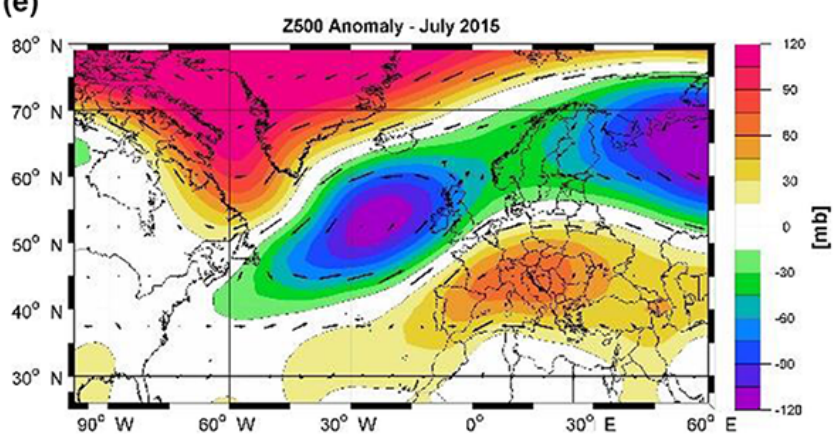

(g)

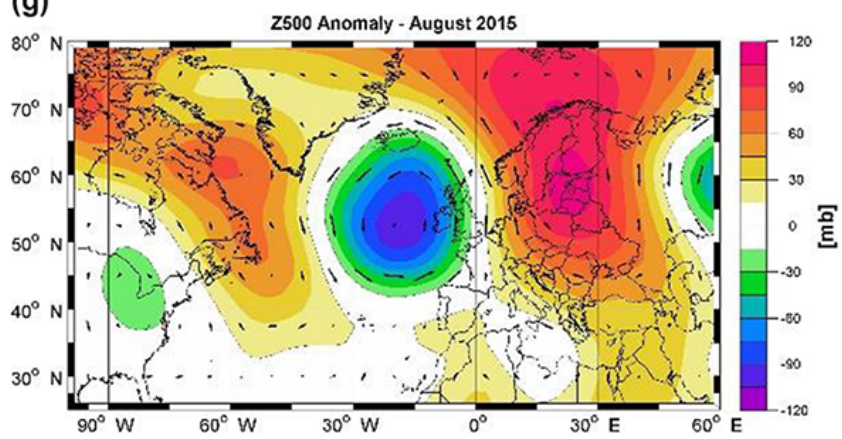

(b)

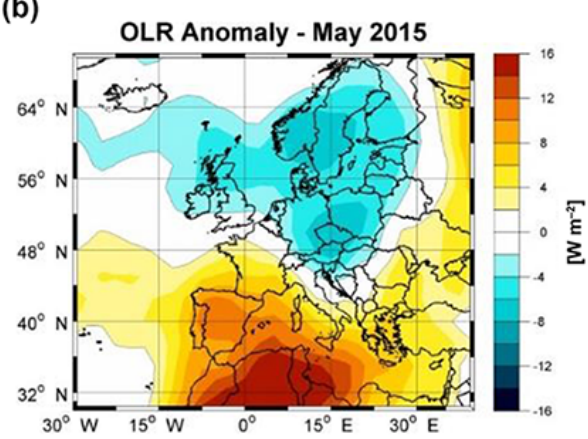

(d)

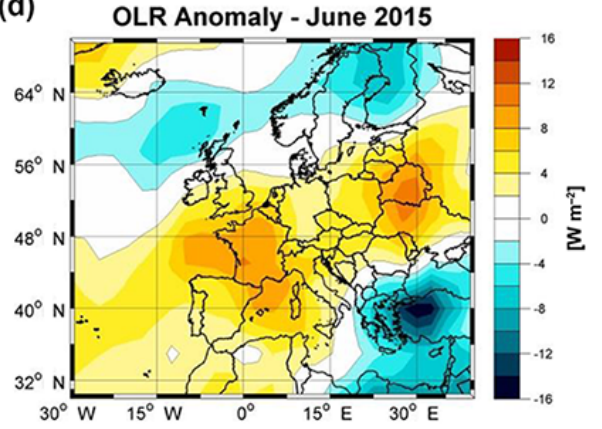

(f)

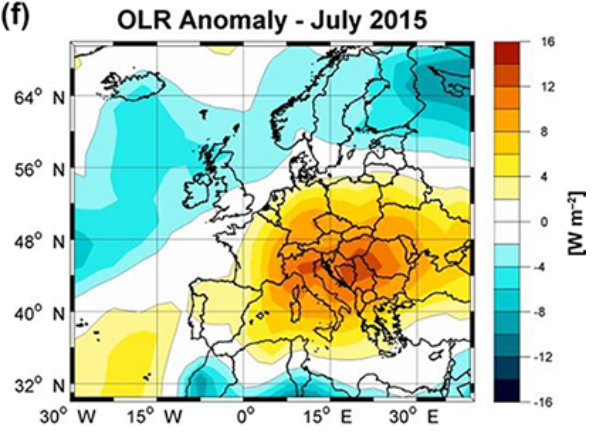

(h) OLR Anomaly - August 2015

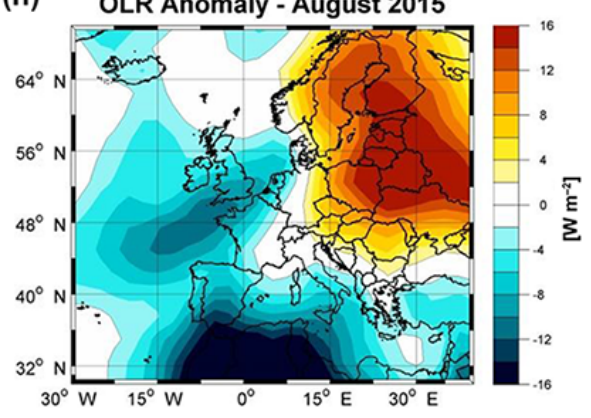

Figure 6. Monthly Z500 anomalies (left column) and OLR anomalies (right column). (a) and (b): May 2015. (c) and (d): June 2015. (e) and (f): July 2015. (g) and (h): August 2015. The anomalies for Z500 and ORL are computed relative to the period 1971-2000.

streamflow anomalies are associated with a more zonal circulation and with moisture inflow from the Atlantic Basin.

The large-scale Z500 anomalies identified throughout the 2015 summer had a similar structure to the low-level anomalies (Fig. S7), indicating an approximately equivalent barotropic vertical structure. Moreover, the wave-trainlike pattern of alternating Z500 anomalies and the stream- function anomalies at $850 \mathrm{hPa}$ (Fig. S8) suggest a Rossby wave signal propagating from the USA to Russia. These findings are consistent with the findings of Schubert et al. (2014), which have shown that droughts and heat waves over the Eurasian continent are often associated with the occurrence of stationary Rossby waves. For example, the 2003 European and 2010 Russian heat waves were driven mainly by a sta- 
tionary Rossby wave that extended across northern Eurasia (Schubert et al., 2011). Under the influence of $\Omega$ blocks and northward-shifted storm tracks, warm dry air from southern Europe and Africa was pulled northward, pushing temperatures higher than normal over the Iberian Peninsula, central Europe and the Balkans.

The heat waves, associated blocking episodes and northward shift of storm tracks throughout the 2015 summer may have been caused by higher-than-average SSTs in the Mediterranean Sea (Figs. 4 and 5). A similar situation was observed in the summer 2003. Modeling results (Feudale and Shukla, 2007, 2010b) indicate that exceptionally warm SSTs over the Mediterranean Sea and the central North Atlantic Ocean could be responsible for shifting the jet stream northwards, leaving Europe under drought conditions and heat waves.

\subsection{Teleconnection patterns}

Numerous previous studies have shown the importance of teleconnection patterns in modulating the climate of Europe in different seasons (e.g., Hurrell, 1995; Trigo, 2004; Andrade et al., 2012; Casanueva et al., 2014; Ionita, 2014; Ionita et al., 2015). Here, we investigate the role of these teleconnection patterns in the drought conditions in summer 2015. The first eight months of 2015 were characterized by altering phases of some teleconnection patterns or by a persistent positive or negative phase.

The teleconnection patterns previously shown to have the strongest impact on European precipitation and temperature, and hence drought conditions, are the NAO, the EA and the SCA teleconnection patterns (Hurrell, 1995; Barnston and Livezey, 1987; Comas-Bru and McDermott, 2013; Ionita et al., 2015; Kingston et al., 2015). The NAO was in a positive phase from January until June 2015, followed by an abrupt shift towards the negative phase in July and August (Fig. S9b). In July 2015, the NAO recorded the lowest July value of -3.14 over the last 65 years (Fig. S10b). The negative NAO phase during the summer months was accompanied by a positive phase of the EA pattern (Fig. S9c) and a negative phase of the SCA pattern (Fig. S9d). The recorded values of the SCA index were among the lowest over the last 65 years for the months of May and June 2015 (May: -2.15 and June: -1.52 , Fig. S10d). In summer, a negative NAO is associated with reduced precipitation and high temperatures over the Mediterranean region and the Balkans (Blade et al., 2012). Moreover, a negative summer NAO is associated with anomalously warm SSTs in the Mediterranean basin (Blade et al., 2012), in agreement with our findings from Sect. 3.3. As such, the negative phase of NAO and SCA during the summer months could partially explain the reduced precipitation and high temperatures over the Iberian Peninsula, the central part of Europe, and the Balkans, while at the same time producing increased precipitation and low temperatures over the northern part of Europe in summer 2015. This spa- tial pattern is also seen in a recent study by Casanueva et al. (2014), who find that the main drivers of the summer precipitation over Europe are NAO and SCA, and that the northern part of Europe receives more precipitation during the negative phase of SCA and NAO, whereas the rest of Europe receives less precipitation and, thus, is more exposed to droughts.

\section{Long-term context of the summer 2015 drought event}

\subsection{Similarities and discrepancies with summer 2003}

Since there are indications of future increases in the frequency of heat waves and droughts in multiple European regions (Christensen et al., 2007; Orlowsky and Seneviratne, 2012; Prudhomme et al., 2013; Van Huijgevoort et al., 2014; Giuntoli et al., 2015; Wanders et al., 2015), it is important to analyze the most extreme events at a pan-European scale and to study the underlying processes in a consistent manner. One way to address this is to analyze the precursors and background mechanisms for different extreme events and to look for similarities and/or discrepancies. The summer drought of 2015 is one of the worst droughts since the event of 2003. Summer 2003 was notable for three reasons: (i) the surface temperature anomalies associated with the heat wave were more than 5 standard deviations above the mean in some parts of Europe (Schär et al., 2004); (ii) the high precipitation deficit and evapotranspiration losses led to water shortages, temporary cessation of agricultural activities and even the temporary shutdown of various power plants (Stahl et al., 2016) and (iii) it caused around 70000 heat-related deaths, mainly in the western and central parts of Europe (Robine et al., 2008).

Spring and summer of 2003 were characterized by reduced precipitation over most of the central and southern parts of Europe (Figs. S11a and S12a). The precipitation deficit became visible at the end of the winter season. Summer 2003 was characterized by a very dispersed pattern of precipitation deficits, with a series of relatively small regions affected by record-breaking precipitation deficits (Fig. 7a). Contrary to 2003, winter 2015 was rather wet over the areas affected later by droughts in summer and the precipitation deficit only became detectable at the end of spring (over the Iberian Peninsula, France and Germany; Fig. S11b). Summer 2015 was further characterized by a more homogenous deficit pattern, with extreme precipitation deficits over large areas covering the eastern part of Europe (Fig. 7b).

The year 2003 experienced the warmest summer on record over most of central Europe, including the northwestern parts of Spain, France, Italy, Germany, Switzerland and Austria, and the western part of the Czech Republic (Fig. 7c). Positive anomalies in daily maximum temperature $\left(\sim 2{ }^{\circ} \mathrm{C}\right)$, were seen first in spring over the Iberian Peninsula, France, the British Isles, Benelux and Germany (Fig. S11c). This pat- 
(a)

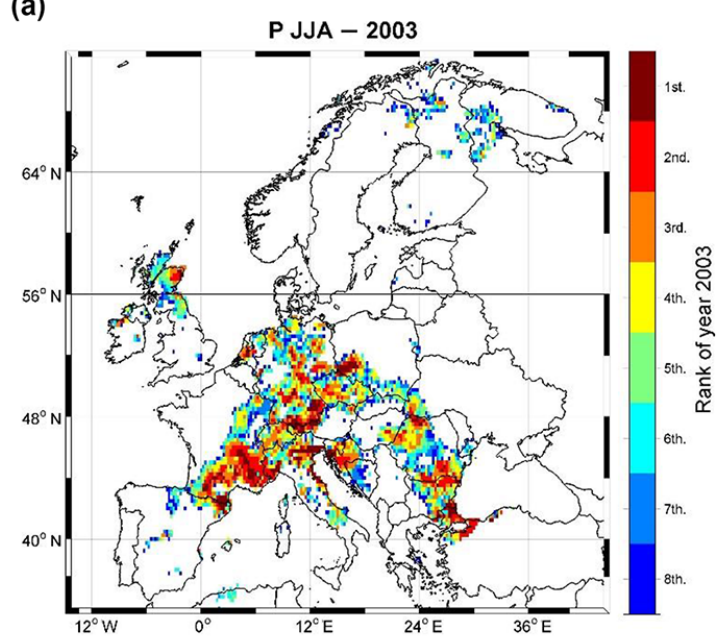

(b)

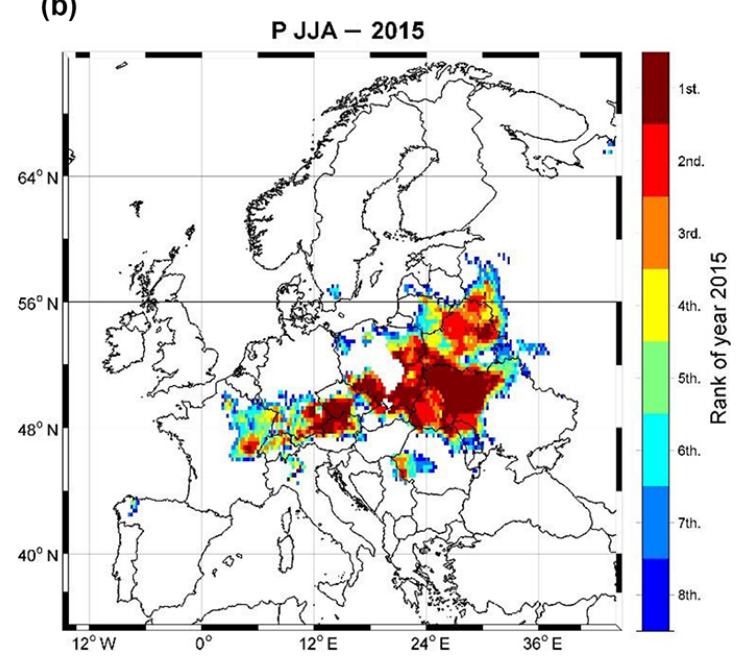

(d)

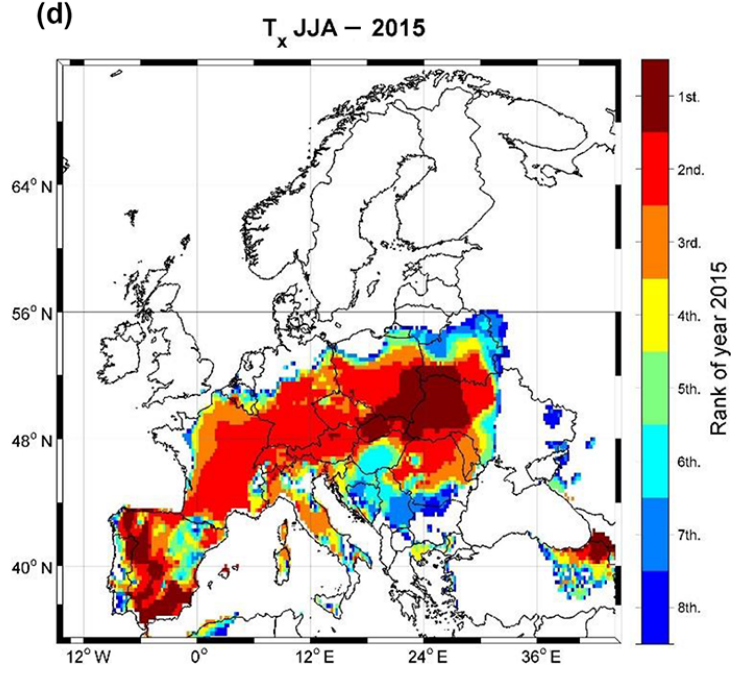

Figure 7. (a) Top-eight ranking of 2003 summer $P$; (b) Top-eight ranking of 2015 summer $P$; (c) Top-eight ranking of 2003 summer $T_{x}$ and (d) Top-eight ranking of 2015 summer $T_{x} .1$ means the driest $(P)$ and warmest $\left(T_{x}\right)$ summer since 1950, 2 signifies the second driest, etc., and all ranks greater than 8 are shown in white. Analyzed period: 1950-2015.

tern amplified in summer, peaking in August, when Europe registered the warmest summer in the last 500 years (Luterbacher et al., 2004), with record-breaking temperatures in the western and central parts of Europe (Fig. S12c). In spring 2015, maximum temperature anomalies were recorded over the Iberian Peninsula $\left(\sim 2^{\circ} \mathrm{C}\right)$, France and the northern part of Fennoscandia (Fig. S11d). However, the affected area was smaller than in spring 2003. In summer 2015, the situation was considerably different, instead with central and southern Europe being affected by heat waves (Fig. S12d). In general, the spatial extent of the precipitation deficit and high temperatures was rather different between 2003 and 2015. In summer 2003, the most affected areas by climatological drought (anomaly in $P$, SPI and SPEI) and heat waves (anomaly in $T_{x}$ ) were the central and western parts of Europe and to some degree Fennoscandia, whereas in summer 2015 the affected regions were extending from central Europe up to the east (Ukraine, Belarus) (Fig. S12).

The SPEI3 and SPI3 seasonal evolution (Figs. 8 and S13), show a similar pattern to the precipitation anomalies (Figs. S11 and S12). Spring 2003 was very dry over the central and southern parts of Europe and this pattern persisted and accentuated in summer 2003 (Figs. 8a, b, S13a, S13b). In spring 2015, a much smaller area was affected, including the Iberian Peninsula, France and the central part of Germany (Fig. S13c and S13d), whereas the northern part of Europe, the Balkans and Belarus were very wet. In 2015, the drought conditions became more evident and accentuated in summer, especially over the eastern part of France, southern part of Germany, Austria and the whole eastern part of Europe (Fig. 8c and d). 
(a)

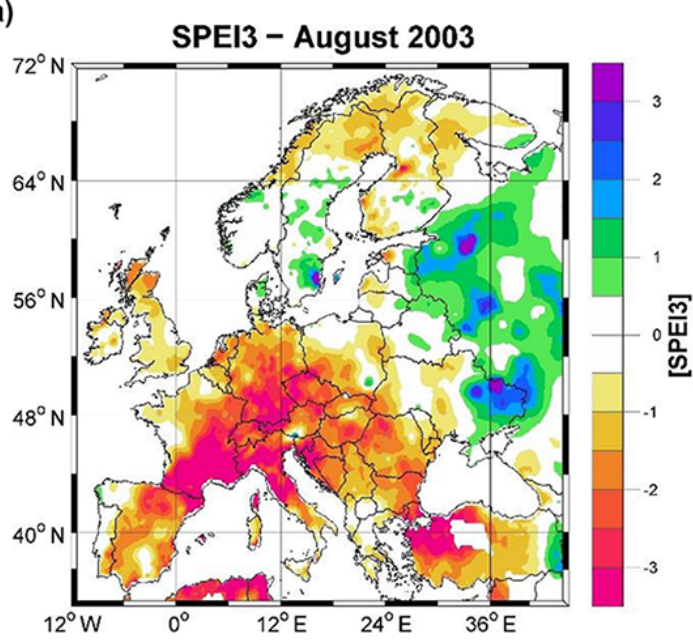

(c)

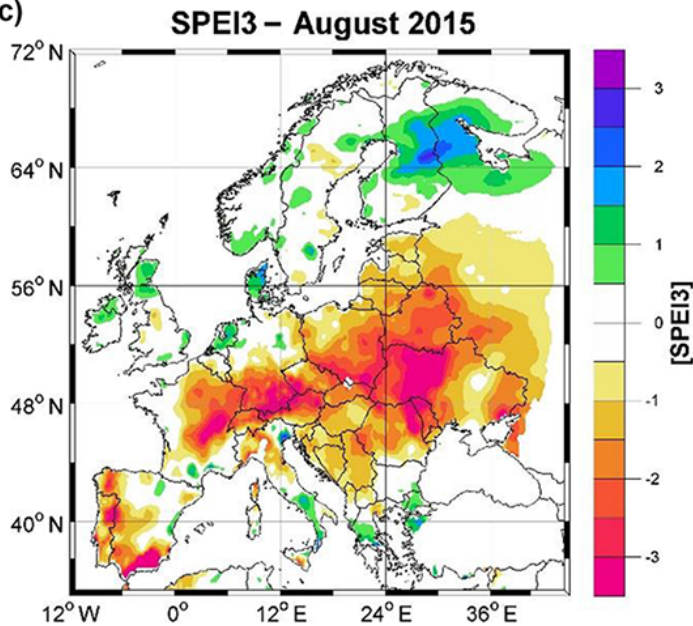

(e)

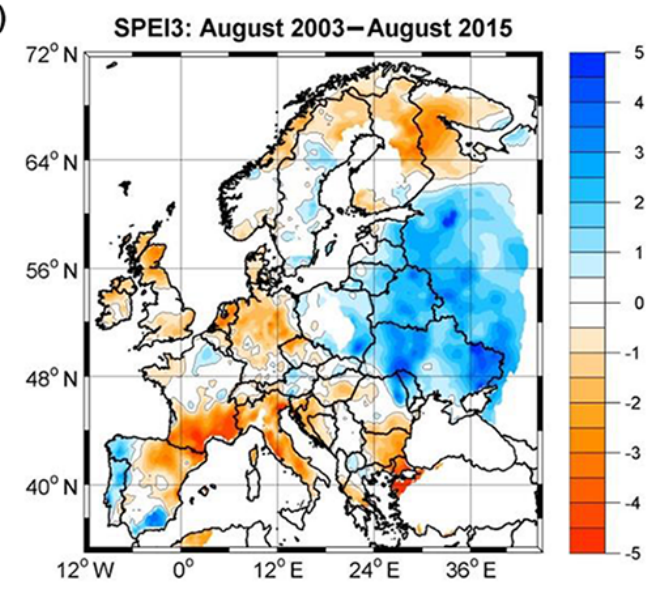

(b)

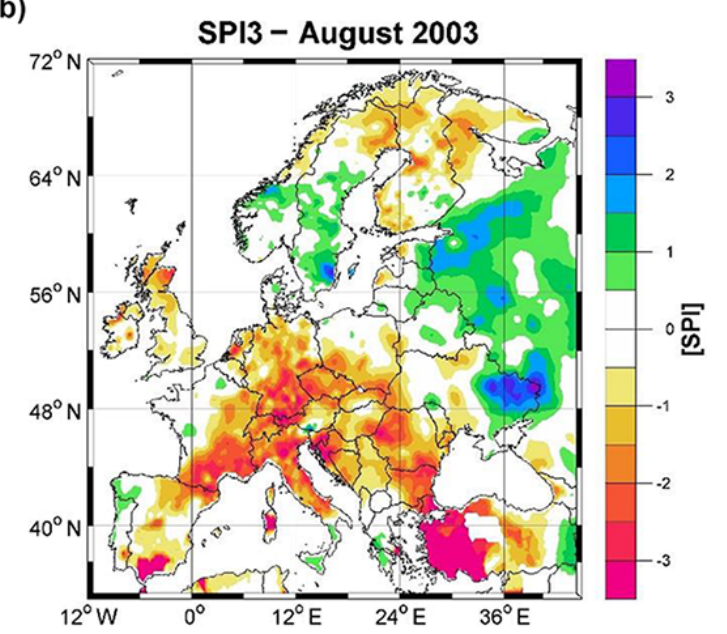

(d)

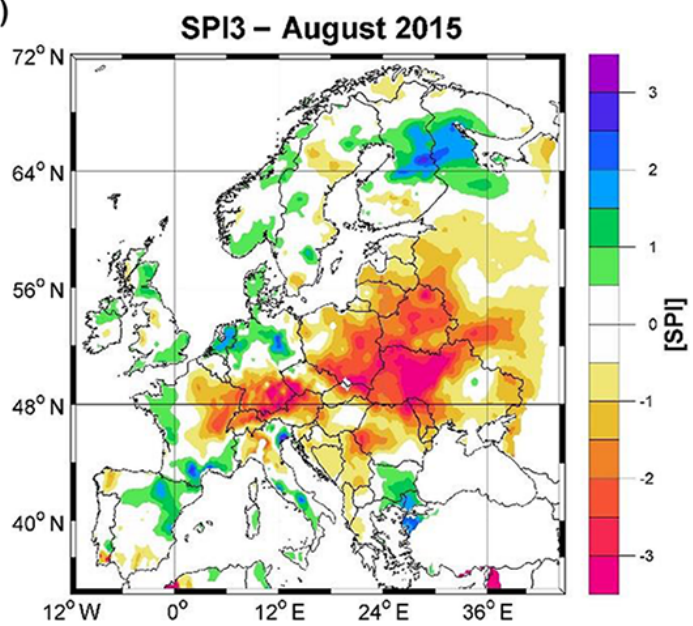

(f)

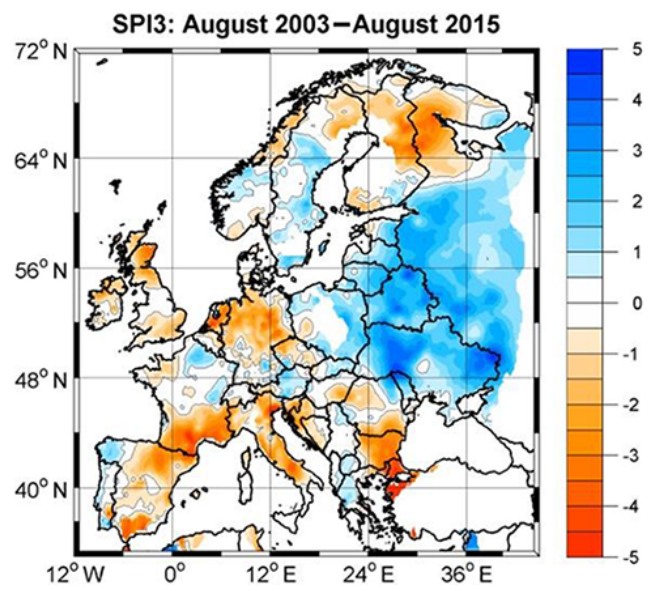

Figure 8. (a) August 2003 SPEI3; (b) as in (a) but for SPI3. (c) August 2015 SPEI3; (d) as in (c) but for SPI3. (e) The difference between August 2003 SPEI3 and August 2015 SPEI3; (f) as in (e) but for SPI3.

The differences between the summer 2003 and 2015 drought is computed for both SPI3 and SPEI3 for the months May (Fig. S13e and S13f) representing the spring season, and August (Fig. 8e and f), reflecting the summer season. As seen from Fig. S13e and S13f, spring 2003 was overall much drier compared to spring 2015 over most of the European continent. In summary, the drought of 2003 was a slowly developing drought, which began much earlier in the year over most 
(a)

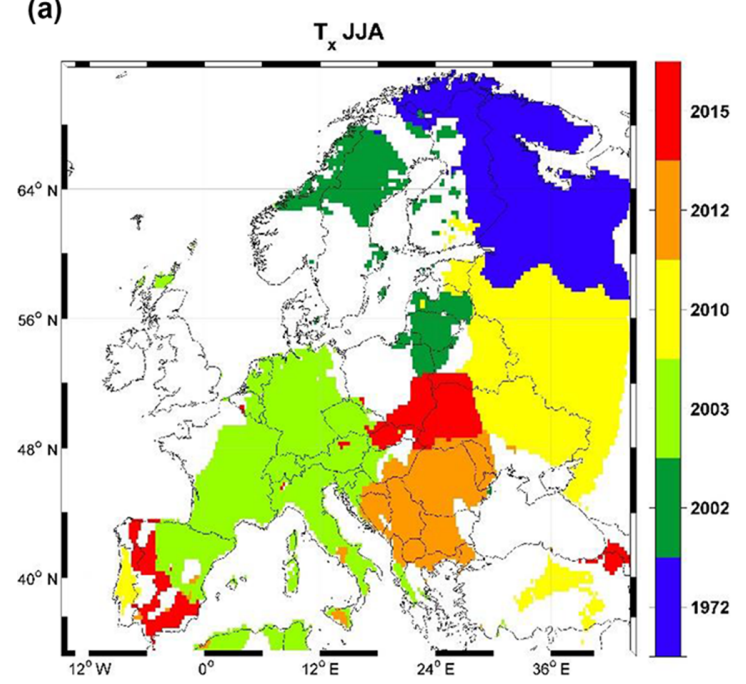

(b)

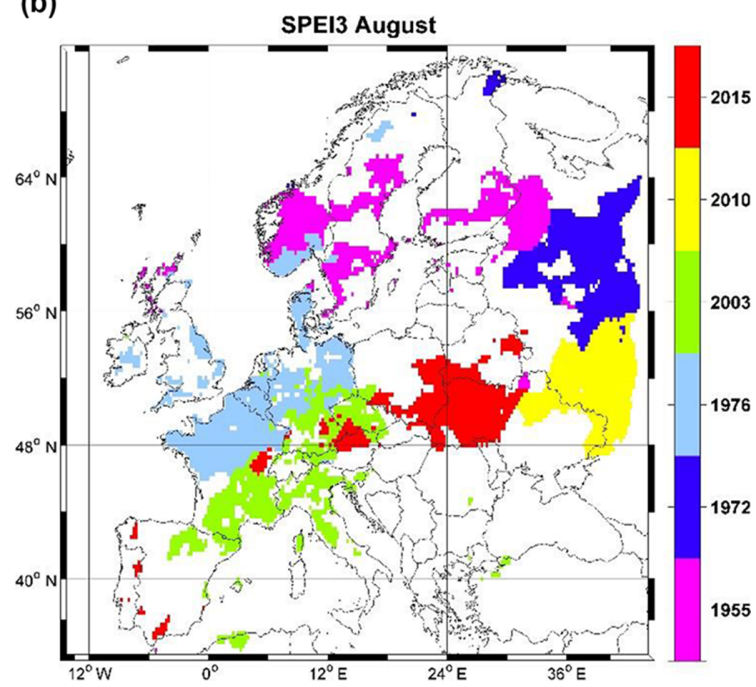

Figure 9. (a) The spatial extent and the year of record of the warmest summers ( $\left.T_{x} \mathrm{JJA}\right)$ over the last 66 years over Europe; (b) is the same as in (a) but for the driest years (SPEI3). Analyzed period: 1950-2015.

of the affected regions. It resulted in extreme high temperatures, affecting mostly western and central Europe, extending from the very south to the north. By contrast, the drought of 2015 had a much more rapid development from its initiation in spring, and a more central and eastern European location, extending from west to east.

Despite the relatively large differences in the initial meteorological conditions of the two events, the SST anomalies in summer 2003 had a similar structure to those recorded in summer 2015 (Fig. S14a and S14b). The central North Atlantic Ocean was cooler than normal in both summers, although in 2003 the cold region was smaller compared to summer 2015. The cold spot in the central North Atlantic Ocean in 2003 was flanked entirely by positive SST anomalies. The main difference between summer 2003 and 2015 in terms of SST anomalies was over the North Sea, which was much warmer in 2003. In contrast, over the Mediterranean Sea the SSTs in both summers were among the three highest on record (Sect. 3.3 and Fig. 11d). According to modeling studies, a warm Mediterranean Sea alone could not produce the heat wave, but it can reinforce it through increased oceanic heat flux to the atmosphere (Feudale and Shukla, 2007). Moreover, for summer 2003 the North Sea and the surrounding North Atlantic Ocean were also very warm and could have played a role in the development of the heat wave by reducing the baroclinicity in the European region and enhancing blocking situations (Feudale and Shukla, 2010a).

In summer 2003, the upper-level atmospheric circulation was characterized by a large positive Z500 anomaly over Europe flanked by negative Z500 anomalies over the central North Atlantic Ocean and over Belarus, Ukraine and western Russia (Fig. S14c). This positive Z500 anomaly over central Europe is connected to an anticyclonic circulation, indi- cating dominant adiabatic descending motion, which results in enhanced incoming solar radiation which in turn warms the surface. In summer 2003, the overall structure of the Z500 anomalies projects onto a typical $\Omega$ blocking structure. The spatial structure of the upper-level atmospheric circulation in summer 2015 is different compared to summer 2003 (Fig. S14d). In summer 2015, the upper-level atmospheric circulation over the European continent was characterized by a large positive Z500 anomaly flanked by a large negative Z500 anomaly to the north and west (i.e., over the central North Atlantic Ocean extending to northern Scandinavia). The Z500 anomalies in summer 2015 resemble the Atlantic Low regime (Cassou et al., 2005). This weather regime is associated with the occurrence of extreme warm days over the western and southern parts of Europe in summer, due to advection of warm air masses form northern Africa and the Mediterranean Sea.

Although the overall spatial structure of the Z500 anomalies for the two extreme summers are not similar, they are both associated with anticyclonic circulations over Europe, flanked by cyclonic circulation over the surrounding areas and with a very warm Mediterranean Sea and tropical Atlantic Ocean, and a cold central North Atlantic Ocean. As previously shown, the anticyclonic circulation in summer over Europe could be strongly influenced by the tropical Atlantic Ocean, due to a northward shift in the Intertropical Convergence Zone (ITCZ) position (Cassou et al., 2005). Based on modeling and observational studies, it has been shown that the probability of heat waves occurring over Europe is much higher when the tropical forcing is taken into account (Cassou et al., 2005). The summer 2003 drought and heat wave was the consequence of a prolonged dry period characterized by persistent anticyclonic circulation, which 
(a)

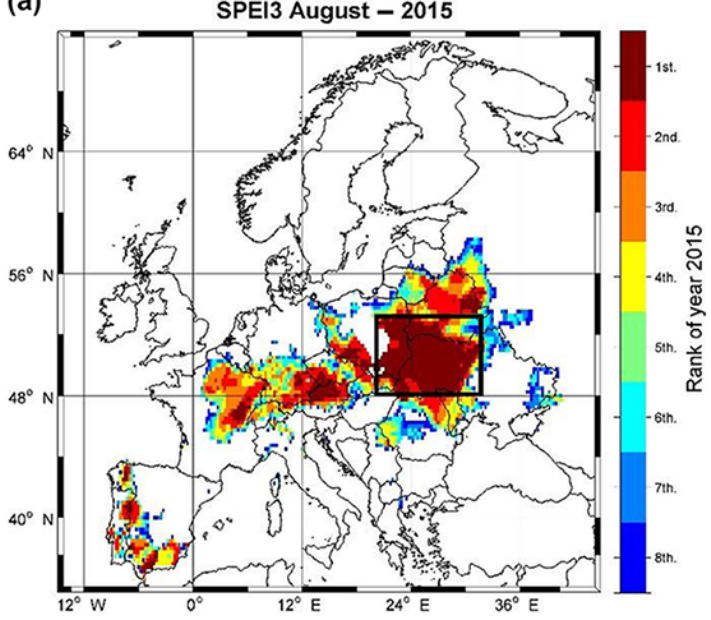

(c)

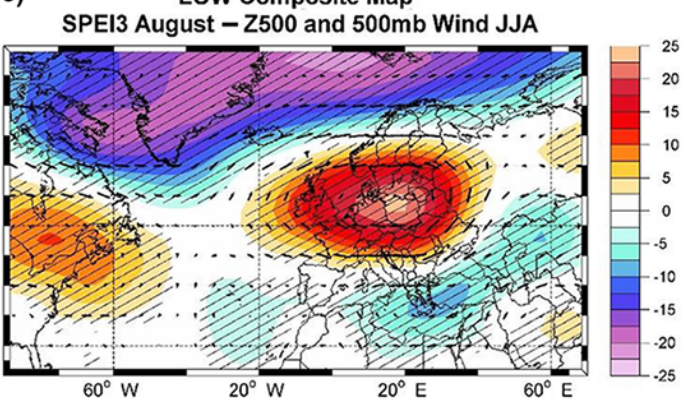

(b)
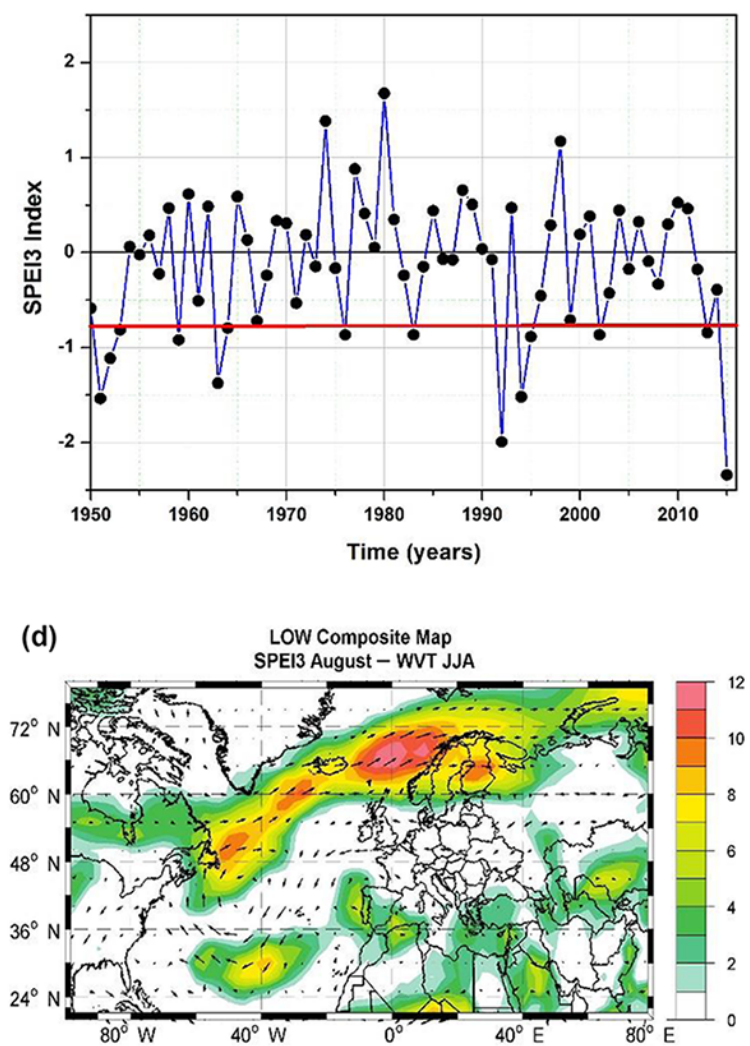

(f)

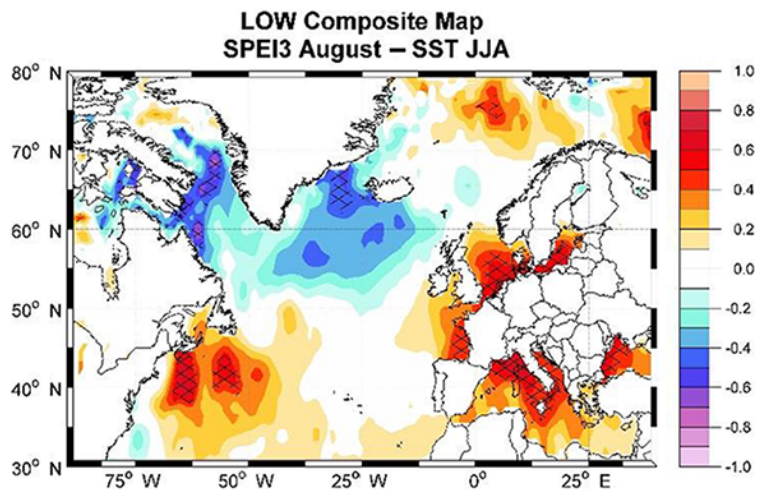

Figure 10. (a) Top-eight ranking of 2015 August SPEI3. (b) The time series of August SPEI3 index averaged over the black box in (a). (c) The low (SPEI3 August index $\leq 0.75$ standard deviation) composite map between the August SPEI3 index and the JJA Z500 and the wind vectors at $500 \mathrm{mb}$; (d) the same as (c) but for the JJA WVT; (e) is the same as (c) but for the JJA $T_{x}$ and (f) is the same as (c) but for the JJA SST. Units: Z500 (m), WVT $\left(\mathrm{kg} \mathrm{m} \mathrm{s}^{-1}\right), T_{\max }\left({ }^{\circ} \mathrm{C}\right)$ and SST $\left({ }^{\circ} \mathrm{C}\right)$. The hatching highlights significant values at a confidence level of $95 \%$. Analyzed period: $1950-2015$. 
(a)

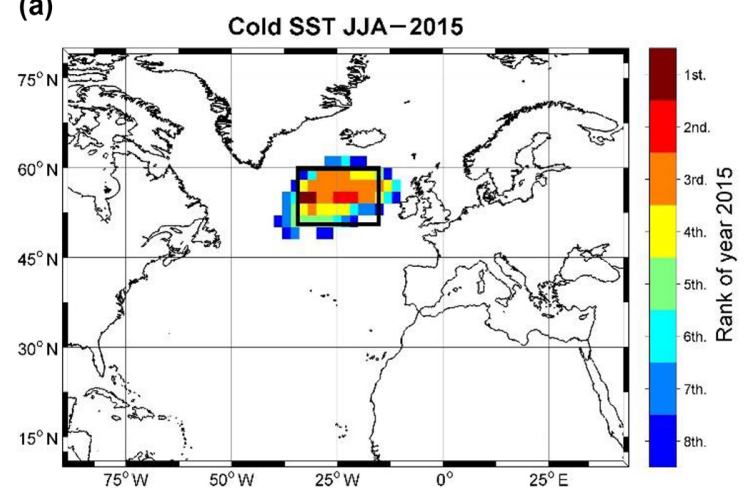

(c)

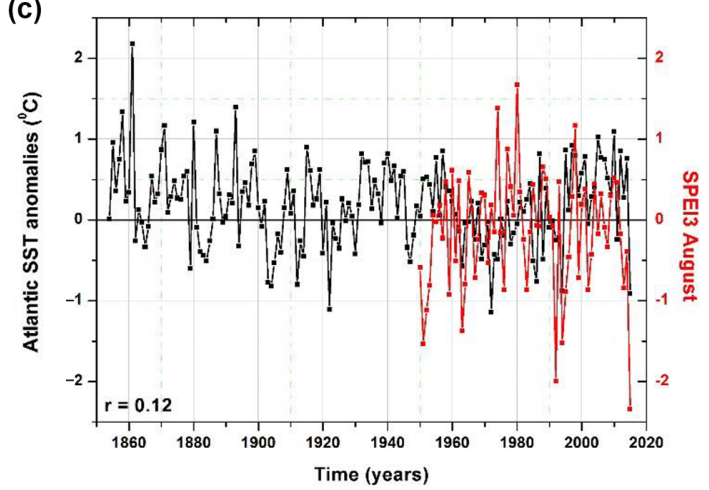

(b)

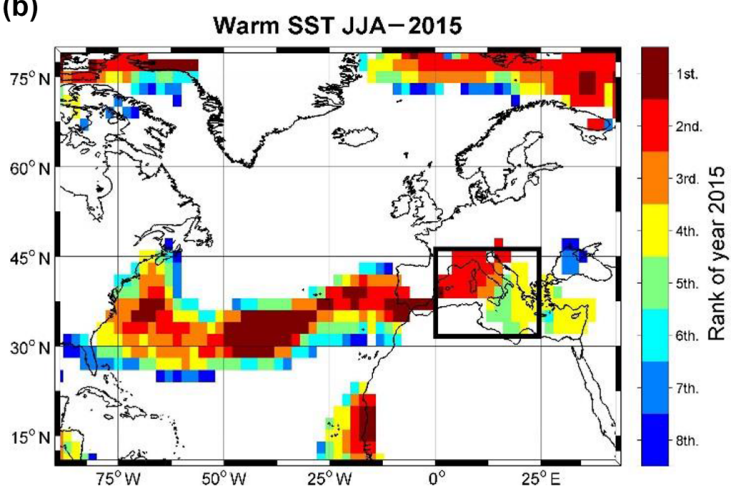

(d)

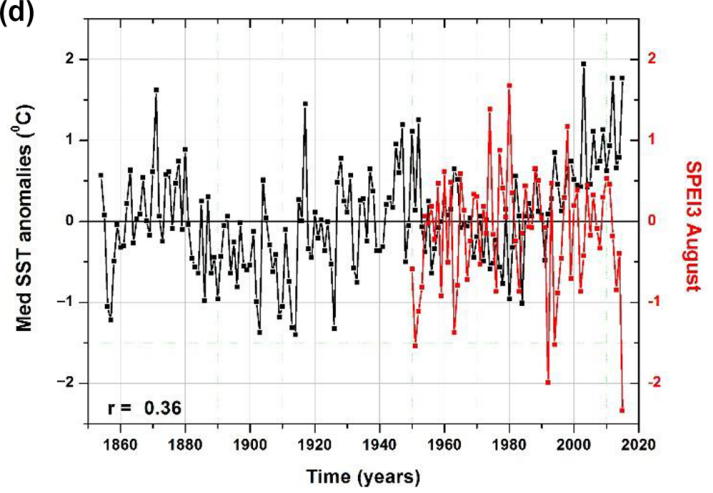

Figure 11. (a) Top-eight ranking of 2015 summer (JJA) cold SST. (b) Top-eight ranking of 2015 summer (JJA) warm SST. (c) The time series of JJA cold-SST index averaged over the black box in (a) (black line) and the time series of August SPEI3 index averaged over the black box in Fig. 7a (red line). (d) The time series of JJA warm-SST index averaged over the black box in (b) and the time series of August SPEI3 index averaged over the black box in Fig. 7a (red line). The Atlantic SST index and the Med SST index are based on the ERSSTv4b dataset (Liu et al., 2014). Analyzed period: 1854-2015.

had already started at the end of winter; the drought in summer 2015 originated much later, i.e., at the end of spring (Fig. S13 and S15).

\subsection{Comparison with other extreme dry and hot summers}

To assess the severity of the summer 2015 drought and heat wave in a long-term context, the daily maximum temperature for JJA and SPEI3 for August over the study period (19502015 ) is analyzed. The six warmest (the highest daily maximum temperatures recorded at each grid point, Fig. 9a) and driest (Fig. 9b) summers on record and their spatial extent are shown in Fig. 9. (It is interesting to note that five out of the six hottest summers were recorded in the last 15 years.) The only exception is the summer of 1972. Each of these summers extended over well-defined regions: 1972 - eastern parts of Fennoscandia and northwestern parts of Russia, 2002 - central parts of Norway and Belarus, 2003 - eastern parts of the Iberian Peninsula and central parts of Europe, 2010 the Balkan region, 2010 - western parts of Russia and 2015 southern parts of the Czech Republic and Ukraine. The summers 1972, 2003 and 2015 affect the largest regions in terms of extreme temperatures. In a recent publication, Russo et al. (2015) have shown, by using a more complex definition of the heat wave concept, that the heat waves recorded in July 1972 in Finland and in the summer of 2003 were the strongest heat waves observed in the record.

Three out of the six driest summers in terms of high climatic water deficit (as measured by the SPEI3), i.e., 1955, 1972, 1976, 2003, 2010 and 2015, occurred in the last 15 years (Fig. 9b). The summers of 1972, 2003, 2010 and 2015 stand out as both very hot and dry, indicating that the high climatic water deficit $(P-\mathrm{PE})$ had a strong influence on the occurrence of droughts. In contrast, the summers of 1955 and 1976 stand out as very dry, but not extremely hot, indicating that these dry summers may be driven mainly by precipitation deficits.

\subsection{Summer droughts and large-scale atmospheric circulation in a long-term context}

To examine the drivers of historical droughts, including the extreme summer 2015 event, an August SPEI3 index was created, defined as the mean SPEI3 within the most-affected region (black box in Fig. 10a, Sect. 3.2). By means of this 
index, composite maps were created to show the mean atmospheric circulation and North Atlantic SSTs for the driest summers (regional SPEI3 index $<0.75$ ), including 1951, 1952, 1953, 1959, 1963, 1964, 1976, 1983, 1992, 1994, 1995, 2002 and 2015 (Fig. 10b). It is interesting to note that 2003, generally considered a benchmark drought in western Europe, is not considered an extreme year in terms of SPEI3 for this region due to its slightly different climate drivers (see Sect. 5).

Dry years in the eastern European region that was the focus of the summer 2015 event are usually associated with a tripole-like pattern of a large positive Z500 anomaly over the central and eastern parts of Europe, flanked by a large negative Z500 anomaly to the north and southeast (i.e., over Greenland and the Mediterranean Sea) (Fig. 10c). Summer (SPEI3) droughts in this region are also associated with a northward deflection of the Atlantic storm tracks (Fig. 10d), which produces exceptionally warm summer temperatures for most of Europe, centered over eastern Europe (Fig. 10e). North Atlantic SSTs during these events are characterized by a tripole-like pattern, with altering signs of SST anomalies over the North Atlantic basin and the Mediterranean Sea. Dry summers over the eastern part of Europe are associated with positive SST anomalies on the eastern coast of the USA and over the Mediterranean and North Sea, negative SST anomalies south of Greenland and positive SST anomalies over the Barents Sea (Fig. 10f). It is worthwhile to note that the anomalies identified in the Z500, WVT, $T_{x}$ and SST fields (Fig. 10), associated with dry summers over the eastern part of Europe, closely resemble the conditions during the 2015 event identified in the previous sections. This suggests that the 2015 drought followed a relatively typical, but extreme, climatological pattern that produces drought in eastern Europe.

Previous studies have emphasized the role of the Atlantic and Mediterranean SST in driving the occurrence of meteorological droughts and heat waves over the European regions (Feudale and Shukla, 2010a, b; Ionita et al., 2011; Kingston et al., 2013). In a recent study, Duchez et al. (2016) have argued that cold SST anomalies in the central North Atlantic Ocean were the main driver of the summer 2015 heat wave over Europe, by initiating a Rossby wave train that favored the development of positive Z500 anomalies and extreme temperature over Central Europe. To test this hypothesis, we compared the same eastern Europe regional SPEI3 index against mean SST anomalies for both the central North Atlantic Ocean (black box in Fig. 11a), where the lowest temperatures were recorded in summer 2015, and the western Mediterranean Sea (black box in Fig. 11b), where the highest temperatures were recorded in summer 2015. During the common period (1950-2015), there was a relatively weak correlation $(r=0.12)$ between the North Atlantic SST index (black line) and the August SPEI3 index (red line). Both indices show the lowest values on record in 2015, but appear to be otherwise unrelated, with dry years (negative SPEI3 index) occurring equally when the central North Atlantic Ocean is cold or warm. Unlike the North Atlantic SST, the western Mediterranean SST index has a significant $(r=-0.36,99 \%$ significance level) correlation with summer SPEI3 in eastern Europe. This suggests a link between drought in eastern Europe and high Mediterranean SST anomalies, though the strong trend in Mediterranean SST data and complex nature of atmosphere-land-ocean feedback warrants more detailed studies.

To further clarify this finding, a reverse analysis was performed, generating composite maps of August SPEI3 (with one season lag and in phase) for anomalously low North Atlantic SST and anomalously high Mediterranean SST, both defined as $\geq 0.75$ standard deviation (Fig. 12). Similar composite maps for summer $T_{x}$ are provided as supplementary figures (Fig. S16a). This analysis confirms that cool North Atlantic SSTs have historically had little effect on meteorological drought in the eastern European region, the most affected during the 2015 drought event (Fig. 12a and c). The only detectable effect of cold North Atlantic SST, particularly in the spring (MAM), is to produce moderate drought over the western part of Germany and Netherlands (Fig. 12a). Alternatively, warm Mediterranean SSTs have historically preceded (Fig. 12b), and occurred concurrently, with summer drought over much of central and eastern Europe. The regions where the significant anomalies are observed in Fig. 15d are similar to those regions affected by drought in summer 2015, further supporting the conclusion that the 2015 drought event followed a historically common (but severe) climate pattern, characterized by a large positive Z500 anomaly over the central and eastern Europe and high Mediterranean SSTs. While the cool North Atlantic SSTs were historically extreme and concurrent with the 2015 drought event, there is no indication that this association has occurred in the recent historical record (60 years), creating some doubt as to its causal effect.

\section{Discussion}

This study has presented the key drivers and characteristics of the summer 2015 drought in Europe. A series of hydroclimatological variables have been investigated to characterize the extraordinary drought of summer 2015 and its dynamic relationship with multiple causal factors, namely the largescale atmospheric circulation, predefined teleconnection indices and SST. Summer 2015 has been identified as the fourth in a series of extreme summers in Europe characterized by droughts and heat waves that started in 2003 (Schär et al., 2004) and continued in 2010 (Barriopedro et al., 2011) and 2013 (Dong et al., 2014). These summers were all characterized by long-lasting droughts, heat waves and record temperatures in different regions, depending on the particular event.

The largest precipitation anomalies in summer 2015 coincided with a very persistent upper-level ridge. The regions 
(a)

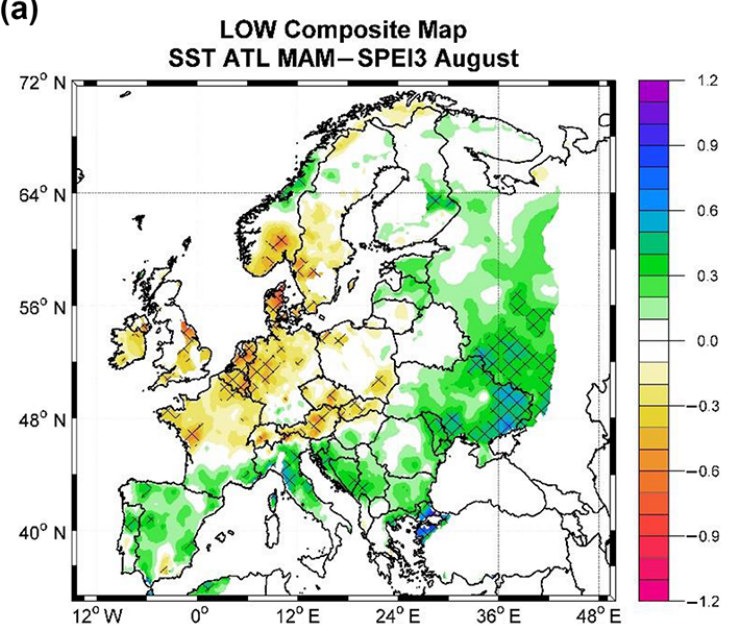

(c)

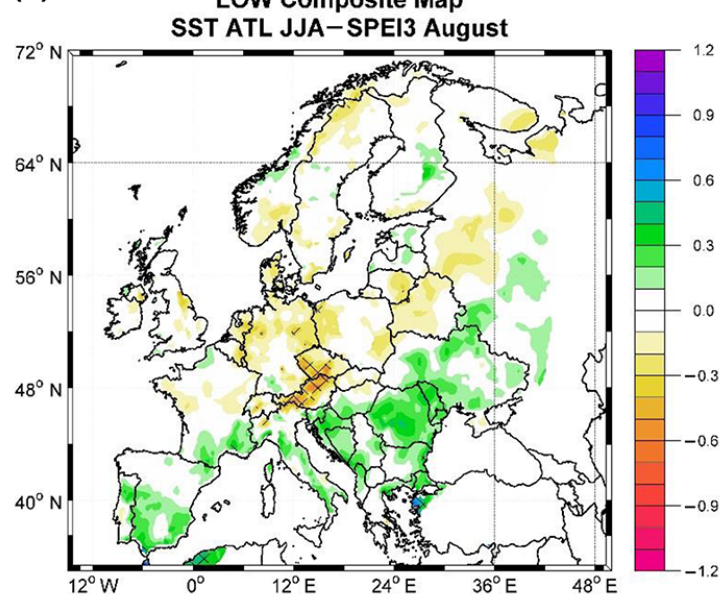

(b)

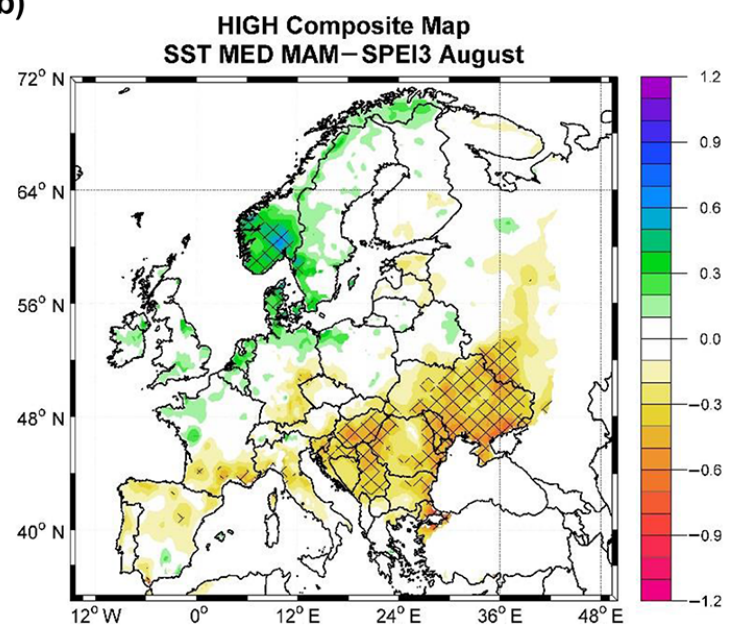

(d)

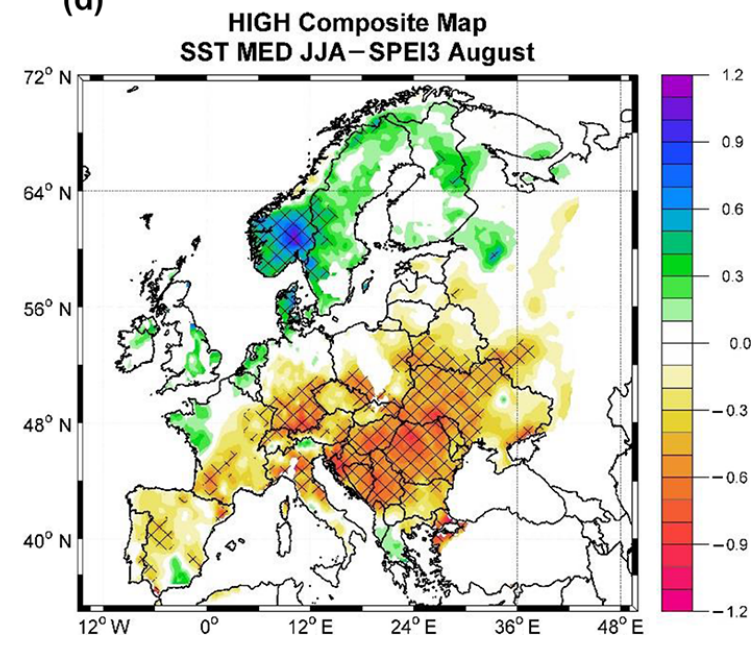

Figure 12. (a) The low (SST cold index $\leq 0.75$ standard deviation) composite map between the spring (MAM) Atlantic SST cold index (defined as the MAM-averaged SST over the black box in Fig. 9a and the August SPEI3 field). (b) The high (SST warm index $\geq 0.75$ standard deviation) composite map between the spring (MAM) Mediterranean SST warm index (defined as the MAM-averaged SST over the black box in Fig. 9b and the August SPEI3 field). (c) is the same as (a) but for summer (JJA) Atlantic SST and (d) is the same as in (b) but for the summer (JJA) Mediterranean SST. The hatching highlights significant values at a confidence level of $95 \%$. Analyzed period: 1950-2015.

most affected by the drought and heat waves were situated south of the axis of the North Atlantic jet stream and were under the influence of large-scale descending motion, reduced precipitation and clear skies. A particular feature of the summer 2015 was a series of four heat wave episodes, all associated with persistent blocking events. These anomalies (precipitation and temperature) are indicative of mechanisms controlled by the radiative forcing, rather than thermal advection. Similar results have been obtained by Andrade et al. (2012), who showed that warm days in summer, over the central and southern parts of Europe, are controlled by radiative forcing enhanced due to persistent high-pressure system.

Over western, central and eastern parts of Europe, the high-pressure system allowed hot air from the tropics to move north and persist over these regions. Clear skies allowed the temperatures to rise even further, creating a stronger center of high pressure, reinforcing the already stagnant $\Omega$ block atmospheric pattern. The high-pressure system acted as a barrier, preventing low-pressure systems from moving over Europe and pushing them instead to the north. Contrary to the situation observed over the western, central and eastern parts of Europe, the British Isles and Fennoscandia were subjected to unstable weather conditions, low temperatures and cloud formation, due to the influence of the low-pressure system there in June and July.

The summer SSTs averaged over the Mediterranean Sea showed that summer 2015 was the third-warmest summer over the last 160 years. Although the very warm Mediter- 
ranean Sea and the occurrence of blocking patterns over Europe are likely to be closely related, the exact mechanism by which the Mediterranean SSTs could influence the atmospheric circulation over Europe is not fully understood (Beniston and Diaz, 2004). Feudale and Shukla (2007) suggested that global SSTs are responsible for the anticyclonic circulation over Europe. By prescribing just the Mediterranean SST anomaly in summer, they show that the upperlevel atmospheric circulation over Europe can be realistically simulated, although with smaller amplitudes than if observed SSTs are used. Opposite to these results, Jung et al. (2006) showed that enhanced SSTs over the Mediterranean Sea had only marginal influence on the mid-tropospheric atmospheric circulation over Europe. Nevertheless, it must be recognized that three of the most extreme summer SPEI3 drought and heat wave events in the last 15 years occurred simultaneously with the highest Mediterranean SSTs on record. Although summer 2015 was also characterized by one of the lowest SSTs in the central North Atlantic, no significant relationship between the occurrence of dry summers over the eastern part of Europe and the central North Atlantic SSTs could be found.

In terms of hemispheric-scale teleconnections, the summer 2015 drought was characterized by a negative phase of the NAO and SCA patterns, including the lowest July value for the NAO in the last 60 years. A negative phase of the NAO and SCA is consistent with dry and warm summers over the central and eastern parts of Europe and wet and relatively cold conditions over the British Isles and Fennoscandia. Specifically, the negative phase of summer NAO is associated with a southward shift in the North Atlantic storm track, which in turn brings wet and cold summers over the UK and Fennoscandia and dry and warm summers over the central, southern and eastern parts of Europe.

When comparing the drivers of summer 2003 and summer 2015 drought and heat wave, some important features stand out:

- The summer 2003 drought and heat wave were caused by a northerly displacement of the Atlantic subtropical high, whereas in summer 2015 all four distinct heat wave episodes were associated with blocking situations and a wavy jet stream.

- The surface temperature anomalies in summer 2003 were more than 5 standard deviations above the mean in parts of Europe (Schär et al., 2004). Due to the exceptional heat wave in summer 2003, the number of fatalities was very high $(\sim 70000)$. In 2015 , the number of fatalities $(\sim 1250)$ was much smaller compared to summer 2003 (MunichRe, 2016).

- For both extreme summers, the central Atlantic Ocean was colder than normal, while the Mediterranean Sea was much warmer than normal $\left(\sim 3^{\circ} \mathrm{C}\right)$. Moreover, record-breaking temperatures were registered in both summers, but in different regions.

- The use of an index-based analysis and composite analysis of central North Atlantic SST and the western Mediterranean SST, on one side, and the August SPEI3 field, on the other side, are not enough to establish causality. Nevertheless, this kind of analysis has shown that warm springs and/or summers over the western Mediterranean Sea are usually associated with summer droughts over the eastern part of Europe. The same is not true for the central North Atlantic SST. The indexbased analysis and composites have shown that a cold central North Atlantic can be associated with either dry or wet summers over the eastern part of Europe.

Both extreme summers were associated with a more meandering polar jet, a circulation structure that has appeared more often during the last few decades in connection with the Arctic amplification phenomena (Cohen et al., 2014). In a recent study, Lehmann and Coumou (2015) showed that changes in the mid-latitude circulation strongly affect the number and intensity of extreme events. They showed that summer heat extremes are associated with low storm track activity, due to a reduced eddy kinetic energy (EKE). Low summertime EKE is significantly linked to positive geopotential height anomalies, and hence has a strong impact on the occurrence of heat waves and droughts. An observed decrease in the EKE in summer has been associated with favorable conditions for heat extremes such as the ones in 2003 and 2010 (Lehmann and Coumou, 2015). The decrease in EKE is in agreement with the observed increasing trend in the frequency and persistence of summertime anticyclonic circulation patterns since 1979 over the Northern Hemisphere, especially over the US, Europe and western Asia (Horton et al., 2015).

The increase in the frequency and persistence of summertime anticyclonic circulation contributed significantly to heat waves and droughts over those regions. Nevertheless, caution should be taken when applying the conclusion from this study about the possible drivers of the drought event, since there are other hemispheric and/or regional mechanisms that also could have played a role (e.g., a weakening of the summer atmospheric circulation (Coumou et al., 2015) and/or the Arctic Amplification (Cohen et al., 2014). Simulations with general circulation models may be also necessary in the future to investigate the full spectrum of causes of severe drought events.

\section{Conclusions and recommendations}

Based on the analysis presented in the previous sections, the following main conclusions can be drawn:

- In a longer-term context, summer 2015 ranks as the hottest and climatologically driest summer since 1950 
over extended regions in eastern Europe. Moreover, summer 2015 ranks also among the six hottest and driest summers since 1950 at the continental scale.

- Five (three) out of the six hottest (driest) summers since 1950 occurred after the year 2000. The summers 1972, 2003, 2010 and 2015 rank as both hot and dry, while the summers 2002 and 2012 rank just as hot, and summers 1955 and 1976 rank just as dry (out of the six hottest and driest years, respectively).

- Throughout the 2015 summer months there were four heat wave episodes, all associated with persistent blocking events and a northward deflection of Atlantic storm tracks.

- Spring and summer 2015 were characterized by a very warm Mediterranean Sea, which can act as a trigger for summer droughts, especially over the southern and eastern parts of Europe.

- Composite analysis showed that the western Mediterranean SST is strongly related to the occurrence of dry and hot summers over the last 66 years (especially over the eastern part of Europe), with the western Mediterranean Sea SSTs leading the SPEI3 by $\sim 25$ days. This lagged relationship between the Mediterranean SST and summer drought conditions can provide valuable skill for the prediction of drought conditions over Europe.

- The extreme temperatures in summer 2003 were amplified by a severe soil-moisture deficit (Schär et al., 2004), as a consequence of a very dry and cold winter and a very dry and warm spring. In contrast to 2003, the drought in 2015 started to develop in late spring. The winter and spring of 2015 were normal in terms of precipitation and temperature anomalies, with small exceptions over the Iberian Peninsula.

- The 2015 drought developed rather rapidly over the Iberian Peninsula, southern Benelux and France in May and reached peak intensity and spatial extent by August, affecting especially the eastern part of Europe.

The study has assessed the severity of the summer 2015 drought event in terms of spatial coverage and the strength of the anomaly, through the use of standardized drought indices (SPI and SPEI), and compared it with the extreme drought of 2003. One important feature of these events, namely the heat waves that accompanied the droughts, was given special attention. However, to assess the full range of drought impacts, many of which are related to a lack of water (Van Lanen et al., 2016), requires additional analyses and data such as soil moisture, groundwater and streamflow observations. Improved management of drought requires a common action of the hydrological and climatic communities that should include monitoring of hydro-meteorological variables, multimonthly and seasonal forecasting of both climatic and hydrological variables, impact assessments, and exploration of potential promising measures to reduce impacts, accounting for the specific conditions at the river-basin scale. As such, drought impact and management studies require a concerted multi-disciplinary action from the climatic and hydrological communities that consider both climate and hydrological controls on drought. This paper, along with its counterparts addressing the hydrological perspective and the impacts of the European drought of 2015 (Laaha et al., 2016; Van Lanen et al., 2016), can be seen as emerging efforts of the climatological and hydrological communities to jointly evaluate the causes and consequence of an extreme event from both perspectives.

Data availability. Our study is based on third party data. The citations to the data sets have been included in the reference list. The data providers are also properly acknowledged in the acknowledgments section.

\section{The Supplement related to this article is available online at doi:10.5194/hess-21-1397-2017-supplement.}

Competing interests. The authors declare that they have no conflict of interest.

Acknowledgements. This study is promoted by Helmholtz funding through the Polar Regions and Coasts in the Changing Earth System (PACES) program of the AWI. Funding by the Helmholtz Climate Initiative REKLIM is gratefully acknowledged. The work forms a contribution to the UNESCO-IHP-VIII, EURO FRIEND-Water Programme. We acknowledge the E-OBS dataset from the EU-FP6 project ENSEMBLES (http://ensembles-eu.metoffice.com) and the data providers in the ECA\&D project (http://www.ecad.eu).

The article processing charges for this open-access publication were covered by a Research Centre of the Helmholtz Association.

Edited by: K. Stahl

Reviewed by: M. G. F. Werner and two anonymous referees

\section{References}

Andrade, C., Leite, S. M., and Santos, J. A.: Temperature extremes in Europe: overview of their driving atmospheric patterns, Nat. Hazards Earth Syst. Sci., 12, 1671-1691, doi:10.5194/nhess-121671-2012, 2012.

Andreu, J., Ferrer-Polo, J., Pérez, M., and Solera, A.: Decision Support System for Drought Planningand Management in the Jucar 
River Basin, Spain, in: 18thWorld IMACS/MODSIM Congress, Cairns, Australia, 13-17 July 2009.

Barnston, A. G. and Livezey, R. E.: Classification, seasonality, and persistence of low-frequency atmospheric circulation patterns, Mon Weather Rev., 115, 1083-1126, 1987.

Barriopedro, D., Fischer, E. M., Luterbacher, J., Trigo, R. M., and García-Herrera, R.: The hot summer of 2010: redrawing the temperature record map of Europe, Science, 332, 220-224, 2011.

Beguería, S., Vicente-Serrano, S. M., Reig, F., and Latorre, B.: Standardized precipitation evapotranspiration index (SPEI) revisited: parameter fitting, evapotranspiration models, tools, datasets and drought monitoring, Int. J. Climatol., 34, 3001-3023, 2013.

Beniston, M. and Diaz, H. F.: The 2003 heat wave as an example of summers in a greenhouse climate? Observations and climate model simulations for Basel, Switzerland, Global Planet. Change, 44, 73-81, 2004.

Blade, I., Liebmann, B., Fortuny, D., and van Oldenborgh, G. J.: Observed and simulated impacts of the summer NAO in Europe: implications for projected drying in the Mediterranean region, Clim. Dynam., 39, 709-727, 2012.

Casanueva, A., Rodríguez-Puebla, C., Frías, M. D., and GonzálezReviriego, N.: Variability of extreme precipitation over Europe and its relationships with teleconnection patterns, Hydrol. Earth Syst. Sci., 18, 709-725, doi:10.5194/hess-18-709-2014, 2014.

Cassou, C., Terray, L., and Phillips, A. S.: Tropical Atlantic influence on European heat waves, J. Climate, 18, 2805-2811, 2005.

Christensen, J. H., Hewitson, B., Busuioc, A., Chen, A., Gao, X., Held, I., Jones, R., Kolli, R. K., Kwon, W.-T., Laprise, R., Magaña Rueda, V., Mearns, L., Menéndez, C. G., Räisänen, J., Rinke, A., Sarr, A., and Whetton, P.: Regional Climate Projections, in: Climate Change 2007: The Physical Science Basis, Contribution of Working Group I to the Fourth Assessment Report of the Intergovernmental Panel on Climate Change, edited by: Solomon, S., Qin, D., Manning, M., Chen, Z., Marquis, M., Averyt, K. B., Tignor, M., and Miller, H. L., Cambridge University Press, Cambridge, United Kingdom and New York, NY, USA, 2007.

Cohen, J., Screen, J. A., Furtado, J. C., Barlow, M., Whittleston, D., Coumou, D., Francis, J., Dethloff, K., Entekhabi, D., Overland, J., and Jones, J.: Recent Arctic amplification and extreme mid latitude weather, Nat. Geosci., 17, 627-637, doi:10.1038/NGEO2234, 2014.

Comas-Bru, L. and McDermott, F.: Impacts of the EA and SCA patternson the European twentieth century NAO - winter climate relationship, Q. J. Roy. Meteor. Soc., 140, 354-363, doi:10.1002/qj.2158, 2013.

Coumou, D., Lehmann, J., and Beckmann, J.: The Weakening Summer Circulation in the Northern Hemisphere Mid-latitudes, Science, 348, 324-327, 2015.

Czaja, A. and Frankignoul, C.: Observed impact of Atlantic SST anomalies on the North Atlantic Oscillation, J. Climate, 15, 606623, 2002

Dong, B.-W., Sutton, R. T., and Shaffrey, L.: The 2013 hot, dry summer in Western Europe, "Explaining Extreme Events of 2013 from a Climate Perspective", B. Am. Meteorol. Soc., 95, S62S66, 2014.

Duchez, A., Frajka-Williams, E., Josey, S. A., Evans, D. G., Grist, J. P., Marsh, R., McCarthy, G. D., Sinha, B., Berry, D. I., and Hirschi, Joël J.-M.: Drivers of exceptionally cold North Atlantic Ocean temperatures and their link to the 2015 European heat wave, Environ. Res. Lett., 11, 074004, doi:10.1088/17489326/11/7/074004, 2016

EC (European Commission): Communication Addressing the challenge of water scarcity and droughts in the European Union, COM(2007) 414 final, European Commission, Brussels, 2007.

EC (European Commission): A Blueprint to Safeguard Europe's Water Resources, COM(2012), 673 final, Brussels, 2012.

EEA (European Environmental Agency): Sustainable water use in Europe, Part 3: Extreme hydrological events: floods and droughts, Environmental Issue Report No. 21, Copenhagen, 2001.

EEA (European Environmental Agency): Mapping the impacts of natural hazards and technological accidents in Europe, An overview of the last decade, EEA Technical report No. 13/2010, Copenhagen, Brussels, 2010.

Feudale, L. and Shukla, J.: Role of Mediterranean SST in enhancing the European heat wave of summer 2003, Geophys. Res. Lett., 34, L03811, doi:10.1029/2006GL027991, 2007.

Feudale, L. and Shukla, J.: Influence of sea surface temperature on the European heat wave of 2003 summer. Part I: an observational study, Clim. Dynam., 36, 1691-1703, doi:10.1007/s00382-0100788-0, 2010a.

Feudale, L. and Shukla, J.: Influence of sea surface temperature on the European heat wave of 2003 summer. Part II: a modeling study, Clim. Dynam., 36, 1705-1715, doi:10.1007/s00382-0100789-z, 2010b.

Giuntoli, I., Vidal, J.-P., Prudhomme, C., and Hannah, D. M.: Future hydrological extremes: the uncertainty from multiple global climate and global hydrological models, Earth Syst. Dynam., 6, 267-285, doi:10.5194/esd-6-267-2015, 2015.

Guttman, N. B.: Accepting the Standardized Precipitation Index: a calculation algorithm, J. Am. Water Resour. As., 35, 311-322, 1999.

Hargreaves, G. H. and Samani, Z. A.: Reference crop evapotranspiration from ambient air temperature, in: Proceedings of the Winter Meeting of American Society of Agricultural Engineers, Chicago, IL, Paper No. 85-2517, 1985.

Hayes, M., Svoboda, M., Wall, N., and Widhalm, M.: The Lincoln declaration on drought indices: universal meteorological drought index recommended, B. Am. Meteorol. Soc., 92, 485-488, 2011.

Haylock, M. R., Hofstra, N., Klein Tank, A. M. G., Klock, E. J., Jones, P. D., and New, M.: A European daily high-resolution gridded dataset of surface temperature and precipitation, J. Geophys. Res.-Atmos., 113, D20119, doi:10.1029/2008JD010201, 2008.

Horton, D. E,. Johnson, N. C., Singh, D., Swain, D. L., Rajaratnam, B., and Diffenbaugh, N. S.: Contribution of changes in atmospheric circulation patterns to extreme temperature trends, Nature, 522, 465-469, 2015.

Hoy, A., Hänsel, S., Skalak, S., Ustrnul, Z., and Bochníček, O.: The extreme European summer of 2015 in a long-term perspective, Int. J. Climatol., 37, 943-962, doi:10.1002/joc.4751, 2016.

Huang, B. and Shukla, J.: Ocean-Atmosphere Interactions in the Tropical and Subtropical Atlantic Ocean, J. Climate, 18, 1652 1672, 2005.

Hurrell, J. W.: Decadal Trends in the North Atlantic Oscillation: Regional Temperatures and Precipitation, Science, 269, 676-679, 1995. 
Ionita, M.: The Impact of the East Atlantic/Western Russia Pattern on the Hydroclimatology of Europe from Mid-Winter to Late Spring, Climate, 2, 296-309; doi:10.3390/cli2040296, 2014.

Ionita, M., Lohmann, G., Rimbu, N., Chelcea, S., and Dima. M.: Interannual to decadal summer drought variability over Europe and its relationship to global sea surface temperature, Clim. Dynam., 38, 363-377, doi:10.1007/s00382-011-1028-y, 2011.

Ionita, M., Lohmann, G., Rimbu, N., and Chelcea, S.: Interannual Variability of Rhine River Streamflow and Its Relationship with Large-Scale Anomaly Patterns in Spring and Autumn, J. Hydrometeorol., 13, 172-188, 2012.

Ionita, M., Boroneant, C., and Chelcea, S.: Seasonal modes of dryness and wetness variability over Europe and their connections with large scale atmospheric circulation and global sea surface temperature, Clim. Dynam., doi:10.1007/s00382-015-25082, online first, 2015.

Jung, T., Ferranti, L., and Tompkins, A. M.: Response to the summer 2003 Mediterranean SST anomalies over Europe and Africa, J. Climate, 19, 5439-5454, 2006.

Kalnay, E., Kanamitsu, M., Kistler, R., Collins, W., Deaven, D., Gandin, L., Iredell, M., Saha, S., White, G., Woollen, J., Zhu, Y., Chelliah, M., Ebisuzaki, W., Higgins, W., Janowiak, J., Mo, K. C., Ropelewski, C., Wang, J., Leetmaa, A., Reynolds, R., Jenne, R., and Joseph, D.: The NMC/NCAR 40-Year Reanalysis Project, B. Am. Meteorol. Soc., 77, 437-471, 1996.

Kingston, D. G., Fleig, A. K., Tallaksen, L. M., and Hannah, D. M.: Ocean-atmosphere forcing of summer streamflow drought in Great Britain, J. Hydrometeorol., 14, 331-344, doi:10.1175/JHM-D-11-0100.1, 2013.

Kingston, D. G., Stagge, J. H., Tallaksen, L. M., and Hannah, D. M.: European-Scale Drought: Understanding Connections between Atmospheric Circulation and Meteorological Drought Indices, J. Climate, 28, 505-516, 2015.

Laaha, G., Gauster, T., Tallaksen, L. M., Vidal, J.-P., Stahl, K., Prudhomme, C., Heudorfer, B., Vlnas, R., Ionita, M., Van Lanen, H. A. J., Adler, M.-J., Caillouet, L., Delus, C., Fendekova, M., Gailliez, S., Hannaford, J., Kingston, D., Van Loon, A. F., Mediero, L., Osuch, M., Romanowicz, R., Sauquet, E., Stagge, J. H., and Wong, W. K.: The European 2015 drought from a hydrological perspective, Hydrol. Earth Syst. Sci. Discuss., doi:10.5194/hess2016-366, in review, 2016.

Lehmann, J. and Coumou, D.: The influence of mid-latitude storm tracks on hot, cold, dry and wet extremes, Nature Scientific Reports, 5, 17491, doi:10.1038/srep17491, 2015.

Liebmann, B. and Smith, C. A.: Description of a Complete (Interpolated) Outgoing Longwave Radiation Dataset, B. Am. Meteorol. Soc., 77, 1275-127, 1996.

Liu, W., Huang, B., Thorne, P. W., Banzon, V. F., Zhang, H. M., Freeman, E., Lawrimore, J., Peterson, T. C., Smith, T. M., and Woodruff, S. D.: Extended Reconstructed Sea Surface Temperature version 4 (ERSST.v4): Part II. Parametric and structural uncertainty estimations, J. Climate, 28, 931-951, doi:10.1175/JCLI-D-14-00007.1, 2014.

Luterbacher, J., Dietrich, D., Xoplaki, E., Grosjean, M., and Wanner, H.: European seasonal and annual temperature variability, trends and extremes since 1500, Science, 303, 1499-1503, 2004.

Mariotti, A., Zeng, N., and Lau, K.-M.: Euro-Mediterranean rainfall and ENSO - a seasonally varying relationship, Geophys. Res. Lett., 29, 1621-1625, doi:10.1029/2001GL014248, 2002.
McKee, T. B. N., Doesken, J., and Kleist, J.: The relationship of drought frequency and duration to time scales, in: Proceedings of the eighth conference on applied climatology, American Meteorological Society, Anaheim, CA, 179-184, 1993.

MunichRe: Overview Natural catastrophes in 2015, http://www.munichre.com/en/media-relations/publications/ press-releases/2016/2016-01-04-press-release/index.html (last access: 15 April 2016), 2016.

NOAA (National Centers for Environmental Information): State of the Climate: Global Analysis for Annual 2015, http://www.ncdc. noaa.gov/sotc/global/201513, last access: 25 January 2016.

Orlowsky, B. and Seneviratne, S. I.: Elusive drought: uncertainty in observed trends and short- and long-term CMIP5 projections, Hydrol. Earth Syst. Sci., 17, 1765-1781, doi:10.5194/hess-171765-2013, 2013.

Peixoto, J. P. and Oort, A. H.: Physics of Climate, Springer, New York, 520 pp., 1992.

Prudhomme, C., Giuntoli, I., Robinso, E. L., Clark, D. B., Arnell, N. W., Dankers, R., Feketee, B. M., Franssen, W., Gerten, D., Gosling, S. N., Hagemann, S., Hannah, D. M., Kim, H., Masaki, Y., Satoh, Y., Stacke, T., Wada, Y., and Wisser, D.: Hydrological droughts in the 21st century: Hotspots and uncertainties from a global multimodel ensemble experiment, P. Natl. Acad. Sci. USA, 111, 3262-3267, doi:10.1073/pnas.1222473110, 2013.

Reynolds, R. W., Smith, T. M., Liu, C., Chelton, D. B., Casey, K. S., and Schlax, M. G.: Daily High-Resolution-Blended Analyses for Sea Surface Temperature, J. Climate, 20, 5473-5496, 2007.

Robine, J. M., Cheung, S., Le Roy, S., Van Oyen, H., Griffiths, C., Michel, J. C., and Herrmann, F.: Death toll exceeded 70,000 in Europe during the summer of 2003, C. R. Biol., 331, 171-178, 2008.

Russo, S., Sillmann, J., and Fischer, E. M. Top ten European heatwaves since 1950 and their occurrence in the future, Environ. Res. Lett., 10, 124003, doi:10.1088/1748-9326/10/12/124003, 2015.

Schär, C., Vidale, P. L., Luthi, D., Frei, C., Haberli, C., Liniger, M. A., and Appenzeller, C.: The role of increasing temperature variability in the European summer heatwaves, Nature, 427, 332336, 2004.

Schubert, S., Wang, H., and Suarez, M.: Warm season subseasonal variability and climate extremes in the Northern Hemisphere: The role of stationary Rossby waves, J. Climate, 24, 4773-4792, doi:10.1175/JCLI-D-10-05035.1, 2011.

Schubert, S. D., Wang, H., Koster, R. D., Suarez, M. J., and Groisman, P.: Northern Eurasian Heat Waves and Droughts, J. Climate, 27, 3169-3207, doi:10.1175/JCLI-D-13-00360.1, 2014.

Seneviratne, S. I.: Climate science: Historical drought trends revisited, Nature, 491, 338-339, doi:10.1038/491338a, 2012.

Spinoni, J., Naumann, G., Vogt, J., and Barbosa, P.: Meteorological droughts in Europe, Events and impacts, past trends and future projections, Publications Office of the European Union, Luxembourg, EUR 27748 EN, 129 pp., doi:10.2788/79637, 2016.

Stagge, J. H., Rizzi, J., Tallaksen, L. M., and Stahl, K.: Future Meteorological Drought Projections of Regional Climate, DROUGHT-R\&SPI Technical Report No. 25, http://www. eu-drought.org (last access: 15 April 2016), 2014.

Stagge, J. H., Tallaksen, L. M., Gudmundsson, L., Van Loon, A. F., and Stahl, K.: Candidate distributions for climatological 
drought indices (SPI and SPEI), Int. J. Climatol., 13, 4027-4040, doi:10.1002/joc.4267, 2015.

Stahl, K., Kohn, I., Blauhut, V., Urquijo, J., De Stefano, L., Acácio, V., Dias, S., Stagge, J. H., Tallaksen, L. M., Kampragou, E., Van Loon, A. F., Barker, L. J., Melsen, L. A., Bifulco, C., Musolino, D., de Carli, A., Massarutto, A., Assimacopoulos, D., and Van Lanen, H. A. J.: Impacts of European drought events: insights from an international database of text-based reports, Nat. Hazards Earth Syst. Sci., 16, 801-819, doi:10.5194/nhess-16-8012016, 2016

Tallaksen, L. M. and Stahl, K.: Spatial and temporal patterns of large-scale droughts in Europe: model dispersion and performance, Geophys. Res. Lett., 41, 429-434, 2014.

Tallaksen, L. M. and Van Lanen, H. A. J.: Hydrological drought: processes and estimation methods for streamflow and groundwater, Developments in water science, 48, Elsevier Science B.V., Amsterdam, the Netherlands, 2004.

Trigo, R. M., Pozo-Vazquez, D., Osborn, T. J., Castro-Diez, Y., Gamiz-Fortis, S., and Esteban-Parra, M. J.: North Atlantic Oscillation influence on precipitation, river flow and water resources in the Iberian Peninsula, Int. J. Climatol., 24, 925-944, 2004.

Van Huijgevoort, M. H. J., Hazenberg, P., Van Lanen, H. A. J., Teuling, R., Clark, D., Folwell, S., Gosling, S., Hanasaki, N., Heinke, J., Koirala, S., Stacke, T., Voß, F., Sheffield, J., and Uijlenhoet, R.: Global multi-model analysis of hydrological drought in the second part of the 20th century (1963-2000), J. Hydrometeorol., 14, 1535-1552, doi:10.1175/JHM-D-12-0186.1, 2013.

Van Huijgevoort, M. H. J., Van Lanen, H. A. J., Teuling, A. J., and Uijlenhoet, R.: Identification of changes in hydrological drought characteristics from a multi-GCM driven ensemble constrained with observed discharge, J. Hydrol., 512, 421-434, doi:10.1016/j.jhydrol.2014.02.060, 2014.
Van Lanen, H. A. J., Laaha, G., Kingston, D. G., Gauster, T., Ionita, M., Vidal, J.-P., Vlnas, R., Tallaksen, L. M., Stahl, K., Hannaford, J., Delus, C., Fendekova, M., Mediero, L., Prudhomme, C., Rets, E., Romanowicz, R. J., Gailliez, S., Wong, W. K., Adler, M.-J., Blauhut, V., Caillouet, L., Chelcea, S., Frolova, N., Gudmundsson, L., Hanel, M., Haslinger, K., Kireeva, M., Osuch, M., Sauquet, E., Stagge, J. H., and Van Loon, A. F.: Hydrology needed to manage droughts: the 2015 European case, Hydrol. Process., 30, 3097-3104, doi:10.1002/hyp.10838, 2016.

Van Loon, A. F. and Van Lanen, H. A. J.: A process-based typology of hydrological drought, Hydrol. Earth Syst. Sci., 16, 19151946, doi:10.5194/hess-16-1915-2012, 2012.

Vicente-Serrano, S. M., Beguería, S., and López-Moreno, J. I.: A multi-scalar drought index sensitive to global warming: the standardized precipitation evapotranspiration index - SPEI, J. Climate, 23, 1696-1718, 2010.

Vicente-Serrano, S. M., López-Moreno, J. I., Gimeno, L., Nieto, R., Morán-Tejeda, E., Lorenzo-Lacruz, J., Beguería, S., and Azorin-Molina, C.: A multiscalar global evaluation of the impact of ENSO on droughts, J. Geophys. Res., 116, D20109, doi:10.1029/2011JD016039, 2011.

Wanders, N., Wada, Y., and Van Lanen, H. A. J.: Global hydrological droughts in the 21 st century under a changing hydrological regime, Earth Syst. Dynam., 6, 1-15, doi:10.5194/esd-6-1-2015, 2015.

Wilhite, D.: Drought: A Global Assessment, Vol I \& II, Routledge Hazards and Disasters Series, Routledge, London, UK, 2000.

WMO (World Meteorological Organisation): Standardized Precipitation Index - User Guide, WMO-No. 1090, Geneva, 2012. 